\title{
Long-Term Hydro-Climatic Trends in the Mountainous Kofarnihon River Basin in Central Asia
}

\author{
Aminjon Gulakhmadov ${ }^{1,2,3,4}\left({ }^{1}, X_{i}\right.$ Chen ${ }^{1,2, *}$, Nekruz Gulahmadov $2,4,5 \oplus$, Tie Liu ${ }^{2} \oplus$, \\ Rashid Davlyatov ${ }^{4,6}$, Safarkhon Sharofiddinov ${ }^{4,6}$ and Manuchekhr Gulakhmadov 1,5,6 \\ 1 Research Center of Ecology and Environment in Central Asia, Xinjiang Institute of Ecology and Geography, \\ Chinese Academy of Sciences, Urumqi 830011, China; aminjon@ms.xjb.ac.cn (A.G.); \\ gmanuchekhr@mail.ru (M.G.) \\ 2 State Key Laboratory of Desert and Oasis Ecology, Xinjiang Institute of Ecology and Geography, \\ Chinese Academy of Sciences, Urumqi 830011, China; nekruz.abdujabborovich@mails.ucas.ac.cn (N.G.); \\ liutie@ms.xjb.ac.cn (T.L.) \\ 3 Ministry of Energy and Water Resources of the Republic of Tajikistan, Dushanbe 734064, Tajikistan \\ 4 Institute of Water Problems, Hydropower and Ecology of the Academy of Sciences of the Republic of \\ Tajikistan, Dushanbe 734042, Tajikistan; drrashid63@mail.ru (R.D.); safar-hush@mail.ru (S.S.) \\ 5 University of Chinese Academy of Sciences, Beijing 100049, China \\ 6 Committee for Environmental Protection under the Government of the Republic of Tajikistan, \\ Dushanbe 734034, Tajikistan \\ * Correspondence: chenxi@ms.xjb.ac.cn; Tel.: +86-991-782-3131
}

Received: 11 June 2020; Accepted: 25 July 2020; Published: 29 July 2020

\begin{abstract}
Hydro-climatic variables play an essential role in assessing the long-term changes in streamflow in the snow-fed and glacier-fed rivers that are extremely vulnerable to climatic variations in the alpine mountainous regions. The trend and magnitudinal changes of hydro-climatic variables, such as temperature, precipitation, and streamflow, were determined by applying the non-parametric Mann-Kendall, modified Mann-Kendall, and Sen's slope tests in the Kofarnihon River Basin in Central Asia. We also used Pettitt's test to analyze the changes during the 1951-2012 and 1979-2012 time periods. This study revealed that the variations of climate variables have their significant spatial patterns and are strongly regulated by the altitude. From mountainous regions down to plain regions, the decadal temperature trends varied from -0.18 to $0.36{ }^{\circ} \mathrm{C} / \mathrm{dec}$ de and the variation of precipitation from -4.76 to $-14.63 \mathrm{~mm} \mathrm{yr}^{-1}$ per decade. Considering the temporal variation, the temperature trends decreased in winter and significantly increased in spring, and the precipitation trends significantly decreased in spring but significantly increased in winter in the high-altitude areas. As consequence, total streamflow in headwater regions shows the obvious increase and clear seasonal variations. The mean monthly streamflow decreased in fall and winter and significantly increased in the spring and summer seasons which can be attributed to the influence of global warming on the rapid melting of snow and ice. Although the abrupt change points in air temperature and precipitation occurred around the 1970s and 1990s in the low-altitude areas and 2000s in the high-altitude areas during the 1951-2012 and 1979-2012 periods, the general trends of hydro-climatic variables keep consistent. This study benefits water resource management, socio-economic development, and sustainable agricultural planning in Tajikistan and its downstream countries.
\end{abstract}

Keywords: temperature; precipitation; streamflow; trends; climate change; Kofarnihon River Basin

\section{Introduction}

The mountainous Kofarnihon River Basin (KRB) in Central Asia has a strong local contrast due to its mountainous topography and is considered the most vulnerable territory in Central Asia to 
hydro-climatic changes [1,2]. The Kofarnihon River (KR), before reaching the Amu Darya River, runs through the capital city of Tajikistan and several high populated districts where people acquire drinking water and irrigate their lands from the KR. In the upstream tributary of the Kofarnihon River, three medium-sized run-of-river hydropower plants (HPPs) and several small size HPPs operate. This river irrigates 44,958 hectares of land in Tajikistan [3].

Mountains with rich biodiversity and ecosystems play an important role in economic services through hydropower generation, tourism, the provision of water resources for agriculture, and livestock production $[4,5]$. Regional climates are also sharpened by these essential ecosystem services. However, these ecosystems are at risk of anthropogenic pressures from overwhelming population growth and impacts from global warming, which further lead to alterations in the hydrological cycle and glacier retreats $[4,6]$. The global warming trend has been obvious during recent decades and relates to the issue of climate change [7].

The global mean temperature has increased by $0.6{ }^{\circ} \mathrm{C}$ in the second half of the 20th century [8]. According to the fifth assessment report (AR5) of the Intergovernmental Panel on Climate Change (IPCC), the global land decadal temperature trend increased over five common periods (1880-2012, 1901-1950, 1951-2012, and 1979-2012) [9-12]. In the Northern Hemisphere, a reduction in the global warming trend was observed mostly in winter [13]. According to Giese et al. [14] and Christensen et al. [15], in Central Asia, the mean temperature increased from 1.2 to $2.1{ }^{\circ} \mathrm{C}$ and from 1 to $2{ }^{\circ} \mathrm{C}$ during the 20th century. The Central Asian region has been facing above-average global warming since the 1950s. The annual temperature in the mountainous region of Central Asia showed an increasing trend during the 1961-2005 time period [16], and Mannig et al. [17] reported the largest climate signal of temperature in winter in the mountainous region of Central Asia after utilizing the high-resolution Regional Model (REMO) during the 1971-2000 time period. Yao et al. [18] confirmed that the trend in annual temperature strongly increased $\left(0.14^{\circ} \mathrm{C} /\right.$ decade $)$ in the Syr Darya River Basin in Central Asia. The mean annual temperature trend increased $\left(0.3{ }^{\circ} \mathrm{C}\right)$ during the $1990 \mathrm{~s}$ in the western region in Central Asia $[18,19]$. Aalto et al. [20] reported that in Tajikistan, the mean annual temperature has increased since the 1930s, with the average rate of variation being about $0.1{ }^{\circ} \mathrm{C}$ per decade [17].

The global annual precipitation showed an increasing trend of $1.1 \mathrm{~mm}$ per decade (with uncertainty of $\pm 1.5 \mathrm{~mm}$ ) during the 1901-2005 period [8]. Annual precipitation has been observed to be different in different regions and locations. According to the IPCC AR5 report, the decadal annual global land precipitation trend decreased. However, in the mid-latitude Northern Hemisphere $\left(30^{\circ} \mathrm{N}-60^{\circ} \mathrm{N}\right)$, the decadal land annual precipitation trend increased [21-24]. Donat et al. [25] confirmed that the climate models and observational data indicate robust increases in precipitation in the world's dry regions, and in wet regions, small variations were found during 1951-2010. Xu et al. [26] observed an increasing trend and also a decreasing trend in precipitation during 1961-2001 in the eastern mountainous region of Central Asia. Similarly, Li et al. [27] confirmed a gradually decreasing trend in annual precipitation in Central Asia at the end of the 20th century. In the region of Central Asia dominated by westerly circulation, Chen et al. [28] reported an increasing trend in precipitation during 1930-2009. From the middle- to high-altitude areas in the northern mountainous region in Central Asia, an increasing trend in annual precipitation reported by Zhang et al. [16] during 1961-2005. Ahmed et al. [29] used a modified Mann-Kendall trend test and noted that the annual precipitation significantly increased during 1961-2015 in the Yangtze River of the Qinghai-Tibetan Plateau. A significant increasing trend in precipitation at a rate of $4.44 \mathrm{~mm} /$ decade was indicated by Yao et al. [18] in the Syr Darya River Basin in Central Asia in the 1881-2011 and 1891-2011 time periods. Chen et al. [28] observed that the mean annual and seasonal precipitation increased in Central Asia and that the largest increase in precipitation occurred in winter during the 1930-2009 time period. Song et al. [30] noted that winter precipitation significantly increased $(0.11 \mathrm{~mm} /$ year $)$ over Central Asia. Song et al. also reported a significant increasing trend in precipitation during winter over the 1960-1991 time period in Central Asia after utilizing different gridded datasets [30]. 
According to Dai et al. [31], the streamflow of the 200 largest rivers globally showed a significant trend and from which 45 of the river flows indicated a decreasing trend, and 19 of the river flows showed an increasing trend during the 1948-2004 time period. Dai et al. [31] and Stocker, [32] after IPCC's 2013 report, concluded that the comprehensive trend analysis of the river flow provides low confidence against a rising trend in the global river flow. In the upstream sub-basins of the Yangtze River Basin in Asia, a decreasing trend in the river flow appeared during the fall season in the middle and mainstream of this river, indicating an increasing trend in summer [33]. Kure et al. [34] found an increasing trend in streamflow in the main rivers in Central Asia. Shen et al. [35] pointed out that the result of the Mann-Kendall trend test showed a significant increasing trend in annual streamflow in the southern Tian Shan Mountains in Central Asia, especially in the spring and winter months during the 1961-2007 period. The Hydrologyska Byrans Vatttenavdelning (HBV) model results showed an increasing trend of the annual runoff $\left(5.51 \mathrm{~mm} \cdot \mathrm{a}^{-1}\right)$ between 1959 and 2009 in the Koxkar River Basin in the western Tian Shan Mountains [36]. The glacier-fed and snow-fed areas of the Lidder and Sindh rivers in the Himalayan Mountains exhibited a statistically significant depleting streamflow during the 1962-2018 period [37]. Lobanova et al. [38] presented an increasing trend in the spring season in the downstream of the Kofarnihon River in Central Asia. The flow in the downstream region of the Kofarnihon River showed a decreasing trend during the winter and fall seasons, and in summer, no trend was indicated [38]. In this study, the streamflow trend analysis was conducted upstream of the Kofarnihon River, where no studies had previously been conducted.

Different statistical methods have been developed and applied to analyze trends in hydro-climatic variables over the years [39-42]. The Mann-Kendall (MK) test and modified Mann-Kendall (MMK) test $[43,44]$ are widely used and commonly accepted as an effective technique to assess the existence of statistically significant trends in climatic and hydrologic data [45-49]. To identify the magnitude of the trend and quantify the significance of the trends in the temperature, precipitation, and streamflow time series, the nonparametric method of Sen's Slope test (SST) [50,51] was used. The abrupt trend detection in a time series used the Pettitt test [52], which is a widely used method [53,54]. In this study, we adopted the MK, MMK, SST, and Pettitt tests. The aim of the present study is to investigate the temperature, precipitation, and streamflow trends for long- and short-term periods (1951-2012 and 1979-2012) considering the annual and monthly temperature, precipitation, and streamflow in the Kofarnihon River Basin. Such studies have not been conducted previously and will greatly improve our understanding of the recent climate changes and hydrological processes in the Kofarnihon River Basin of Central Asia.

\section{Materials and Methods}

\subsection{Study area}

The Kofarnihon River Basin is located in Central Asia and lies between $37^{\circ}$ and $39^{\circ} \mathrm{N}$ and $68^{\circ}$ and $70^{\circ} \mathrm{E}$. It is one of the northwest tributaries of the Amu Darya River (ADR) and the transboundary river between Tajikistan and Uzbekistan. Before confluence with the ADR, the total length of the Kofarnihon River (KR) is $387 \mathrm{~km}$. The total area of the KRB is $11,590 \mathrm{~km}^{2}$. The city of Vahdat and the capital city of Tajikistan, Dushanbe, are located on the KRB. Water is used for drinking in these well-populated cities, for irrigation of the lands of the valley, and for fishing. Kofarnihon River irrigates 44.958 hectares of land in Tajikistan [3] and 70\% of the KRB area is situated in the mountainous region. The main tributaries of this river are Varzob and Khonaqo in the northwest and Elok in the northeast. Elevation in the basin ranges from $304 \mathrm{~m}$ to $4830 \mathrm{~m}$ above sea level. The climate of Tajikistan is determined by its geographical position within the continent of Eurasia on the verge of subtropical and temperate zones. Its characteristic features are a high intensity of solar radiation, aridity, low cloud cover, a long duration of sunshine, sharp fluctuations in daily and seasonal temperatures, and significant dustiness of the air. However, these features manifest themselves differently in individual regions due to the peculiarities in the orographic structures and diversity of the heights of the Earth's surface. In the cold season, 
a polar front is generally located over Tajikistan and Central Asia. Weather conditions form under the influence of cold dry air arriving in the form of cyclones from the Atlantic Ocean. The climate of the KRB is continental under the domination of the westerlies, with very high local contrast due to the geographical terrain. The KRB is occupied by a mountainous climate in the most of its territory, which is characterized by moderate winters in hilly dissected terrain areas, cold winters in mountainous areas, and summer seasons with relatively large annual temperature variations. With an increase of elevation, the temperature decreases, and at different altitudes and features, the precipitation has different patterns. The location of the KRB is shown in Figure 1.

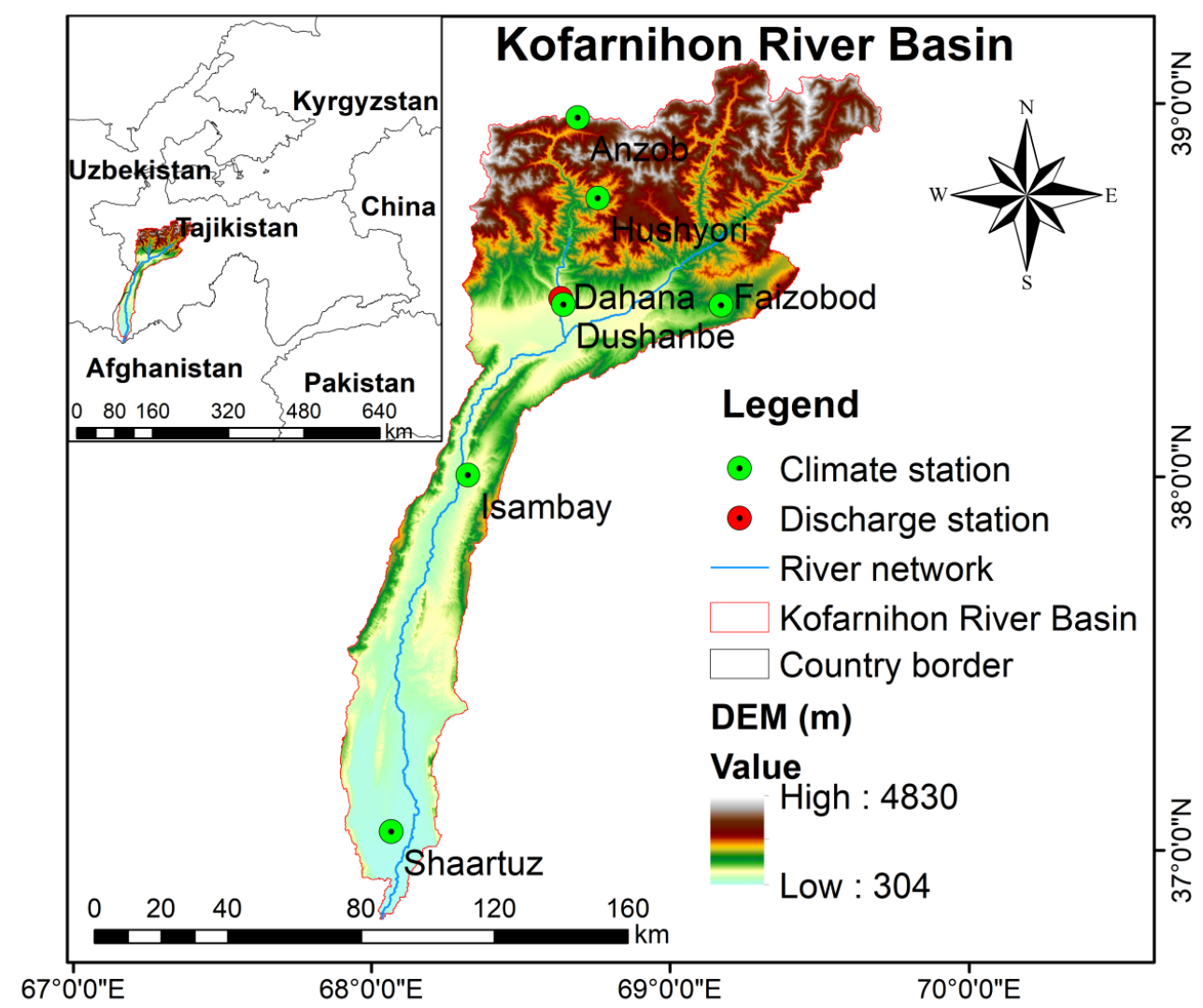

Figure 1. The geographical position and the distribution of the meteorological stations and hydrological station in the study area.

The average water flow in the KR is $164 \mathrm{~m}^{3} / \mathrm{s}$. The minor management of water flow in the KR begins in late February and continues until July, when the flow is at its maximum. The river flow starts to decline in July and continues until January when the river flow is in its lowest condition. The flooding period mostly starts in the first 10 days of March and ends in the third 10 days of September. The river flow from July to September is relatively insignificant. In the fall (October-November) and spring (March-May) seasons, the water flow in the KR is stable. Fall and spring are the two growing seasons in Tajikistan, when precipitation is more intensive. The winter months in the mountains of the KRB are a period of precipitation accumulation in the form of snow mass. The low water flow period occurs in the August and September months when the melting of snow concludes. The conditions for ice melting depend on the climatic features in the relevant period of time. Ice melting can mostly be observed in the areas of the Anzob and Faizobod meteorological stations. In these territories, the climate is not sufficiently humid and has moderately warm summers and mild winters. Isambay station is located in the middle reaches of the KR. In the territory of the Isambay meteorological station in the middle stream of the KR, the climate is not humid enough; the area has very warm summers and mild winters. 


\subsection{Data and Materials}

In this study, we utilized the monthly temperature and precipitation from six meteorological stations and monthly river flow data from one hydrological station in the KRB of Central Asia (Table 1). The monthly data of the temperature and precipitation were supplied from the Agency of Hydrometeorology of the Committee for Environmental Protection under the Government of the Republic of Tajikistan. The hydrological data for the Dahana station were derived from the Ministry of Energy and Water Resources of the Republic of Tajikistan.

Table 1. Location of the climate station under study with coordinates and the monthly mean of air temperature (T), precipitation (P), and streamflow (F) - totals for each season during the 1951-2012 period.

\begin{tabular}{|c|c|c|c|c|c|c|}
\hline WMO Nr & Climate Station & Lat. $\left({ }^{\circ} \mathbf{N}\right)$ & Lon. $\left({ }^{\circ} \mathrm{E}\right)$ & Elev. (m) & $\begin{array}{c}\mathrm{T}\left({ }^{\circ} \mathrm{C}\right) \\
\text { (Win, Spr, Sum, Aut) }\end{array}$ & $\begin{array}{c}\text { P (mm) } \\
\text { (Win, Spr, Sum, Aut) }\end{array}$ \\
\hline 38,719 & Anzob & 39.50 & 68.52 & 3373 & $-1.8(-11.5,-3.1,8.4,-0.8)$ & $308(131,31,67,79)$ \\
\hline 38,833 & Hushyori & 38.53 & 68.50 & 1361 & $11.3(0.3,10.6,22.4,12.0)$ & $1226(403,546,67,210)$ \\
\hline 38,845 & Faizobod & 38.32 & 69.19 & 1215 & $12.9(1.8,12.3,24.0,13.6)$ & $838(250,439,32,117)$ \\
\hline 38,836 & Dushanbe & 38.35 & 68.44 & 800 & $14.7(3.5,14.9,25.8,14.5)$ & $643(223,323,11,86)$ \\
\hline 38,838 & Isambay & 38.3 & 68. 21 & 563 & $16.3(3.6,16.0,29.1,16.3)$ & $311(119,149,11,32)$ \\
\hline 38,937 & Shaartuz & 36.58 & 68.20 & 378 & $17.5(4.8,18.3,30.3,16.7)$ & $187(74,86,6,21)$ \\
\hline WMO Nr & $\begin{array}{l}\text { Discharge } \\
\text { station }\end{array}$ & Lat. $\left({ }^{\circ} \mathrm{N}\right)$ & Lon. $\left({ }^{\circ} \mathrm{E}\right)$ & Elev. (m) & \multicolumn{2}{|c|}{$\begin{array}{c}\mathrm{F}\left(\mathrm{m}^{3} / \mathrm{s}\right) \\
\text { (Win, Spr, Sum, Aut) }\end{array}$} \\
\hline 17,150 & Dahana & 38.59 & 68.77 & 1295 & \multicolumn{2}{|c|}{$46.7(13.1,37.6,103.4,32.8)$} \\
\hline
\end{tabular}

A $30 \mathrm{~m}$ spatial resolution of the Digital Elevation Model was used from the website of the Shuttle Radar Topographic Mission to demarcate the catchment boundary and river network in the KRB [55]. The land-use type of the KRB at a $300 \times 300 \mathrm{~m}$ grid-scale was computed from the Envisat Medium Resolution Imaging Spectrometer [56]. The land cover types for the basin are water body $(0.01 \%)$, forest $(0.82 \%)$, urban area $(1.55 \%)$, snow and ice $(1.94 \%)$, herbaceous cover $(4.75 \%)$, bare land $(10.27 \%)$, shrubland (11.29\%), grassland (33.76\%), and agriculture land (35.62\%). For the KRB, the soil type was determined from version 1.2 of the Harmonized World Soil Database (HWSD) with a scale of 1:5,000,000. The HWSD is freely available on the website of the Food and Agriculture Organization of the United Nations [57]. In this study, the most prominent soil types were cambisols (48.69\%), leptosols (26.60\%), calcisols $(9.79 \%)$, anthrosols (8.37\%), shifting sand dunes $(3.53 \%)$, and arenosols (3.02\%). Mountain gorges, with parents based on soil, include terraces of alluvial deposits, while valleys mainly feature loess rocks, which reach depths of $100 \mathrm{~m}$ and below. Throughout the Kofarnihon River, soil ranges change (from mountain brown to light gray soils and gray-brown soils) with a decrease in the elevation.

In Central Asia, the complexity of the geological structure of the land of the KRB and the diversity of its minerals are due to its location at the junction of the two largest geosynclinal-folded mobile zones, the Ural-Mongolian and Mediterranean, which respectively include the Caledonian-Hercynian North and Mid-Tien Shan and the Herzino-Cimmerian North and South Pamir geosynclinal fold belts. The KRB is based on the geological developments related to Central (Southern Tien Shan and Gissaro-Alai) and South-Western Tajikistan. Central Tajikistan (Gissaro-Alai) is part of the Hercynian geosynclinals, the folded region of South Tien Shan. The geological structure of the latter part mainly includes Middle and Upper Paleozoic and, to a lesser extent, Precambrian, Lower Paleozoic, Mesozoic, and Cenozoic deposits. South-Western Tajikistan is represented by the Tajik depression, the Epigercin Alpine sub-platform, and the eastern flank of the Turan Plate [58].

Tajikistan is included at the center of the origin of cultivated plants, in the Southwest Asia and Central Asian foci. Its flora now includes 5000 species. It is here that the homelands of the most important grains and leguminous crops, such as soft wheat, peas, lentils, and chickpeas, were established. It is recognized that the foothills and mountain zones of Tajikistan are centers of the origin of fruit crops, such as Juglans Regia, Zizyphus Sativa, Pistacia vera L., Pyrus communis L., Amygdalus communis L., Elaeagnus Angustifolia, and Vitis vinifera L. Tajikistan is also notable as the secondary center of origin for a variety of fruit crops: Armeniaca Vulgaris, Malus sieversii, Vitis vinifera, Morus alba L., 
and Punica granatum. Significant in this region are the diversity of wild species and forms of Berberis L., Prunus Sogdiana, Crataegus L., Eleagnus L., and Hippophae rhamnoides L [59].

The inter-annual variation of temperature and precipitation for all six meteorological stations during the 1951-2012 time period is shown in Figure 2. The seasonal temperature and precipitation variability were characterized in winter (December, January, and February), spring (March, April, and May), summer (June, July, and August), and fall (September, October, and November). The coldest and hottest months for all meteorological stations were January and July, with a mean minimum and mean maximum temperature from $-12.1^{\circ} \mathrm{C}$ to $+9.7^{\circ} \mathrm{C}$ at Anzob, from $-17^{\circ} \mathrm{C}$ to $+24.2^{\circ} \mathrm{C}$ at Hushyori, from $+0.4{ }^{\circ} \mathrm{C}$ to $+25.5{ }^{\circ} \mathrm{C}$ at Faizobod, from $+2.3{ }^{\circ} \mathrm{C}$ to $+27.1^{\circ} \mathrm{C}$ at Dushanbe, from $+1.9{ }^{\circ} \mathrm{C}$ to $+30.4{ }^{\circ} \mathrm{C}$ at Isambay, and from $+1.8^{\circ} \mathrm{C}$ to $+31.4^{\circ} \mathrm{C}$ at Shaartuz. The absolute maximum and minimum temperature at all climate stations ranged from $+24{ }^{\circ} \mathrm{C}$ to $-10{ }^{\circ} \mathrm{C}$ at Anzob, from $+39{ }^{\circ} \mathrm{C}$ to $+3{ }^{\circ} \mathrm{C}$ at Hushyori, from $+41{ }^{\circ} \mathrm{C}$ to $-26{ }^{\circ} \mathrm{C}$ at Faizobod, from $-27{ }^{\circ} \mathrm{C}$ to $+46{ }^{\circ} \mathrm{C}$ at Dushanbe, from $+47{ }^{\circ} \mathrm{C}$ to $-27{ }^{\circ} \mathrm{C}$ at Isambay, and from $+47^{\circ} \mathrm{C}$ to $-22^{\circ} \mathrm{C}$ at Shaartuz during the 1951-2012 time period. The annual precipitation at the six reference stations was $494 \mathrm{~mm}$ at Anzob, $1188 \mathrm{~mm}$ at Hushyori, $841 \mathrm{~mm}$ at Faizobod, $653 \mathrm{~mm}$ at Dushanbe, Isambay $306 \mathrm{~mm}$, and $252 \mathrm{~mm}$ at Shaartuz during the 1951-2012 time period.
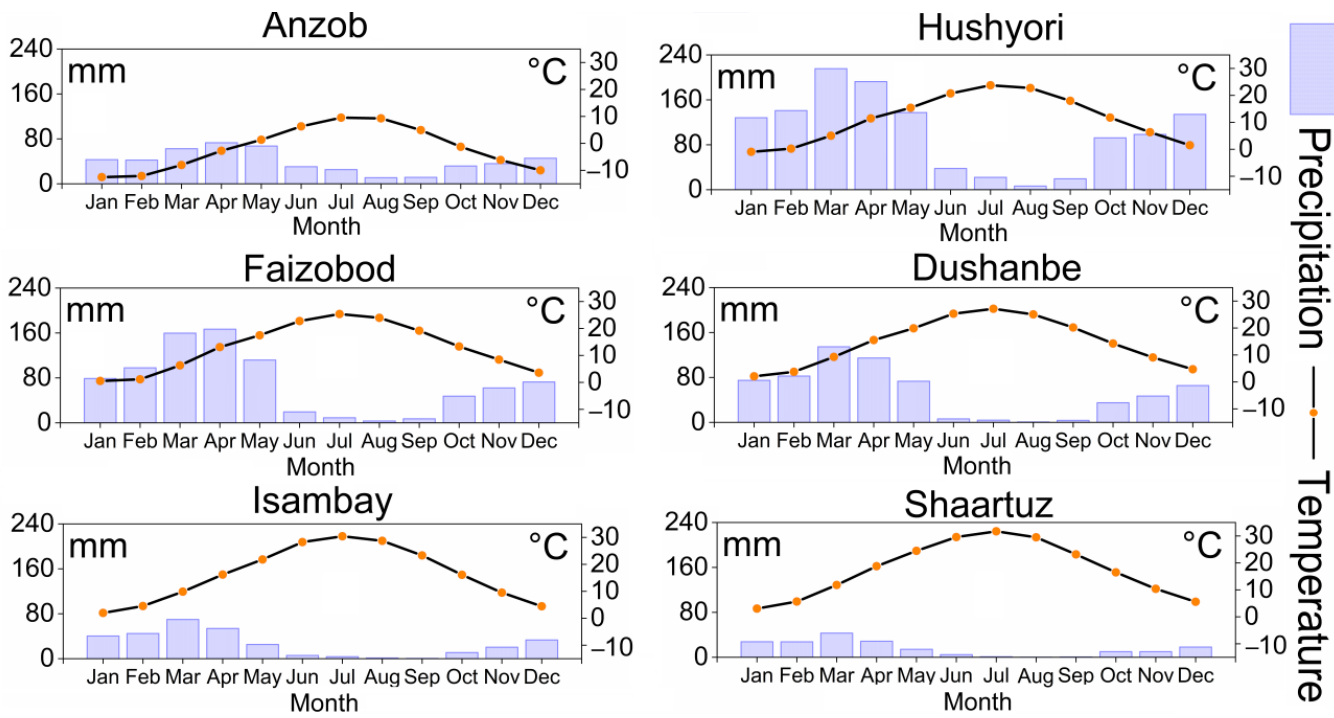

Figure 2. Inter-annual variations in temperature and precipitation during the 1951-2012 period in the Kofarnihon River Basin, Central Asia.

The global temperature trends according to the IPCC report present the temperature per decade; the CRUTEM4.1.1.0 dataset was explored by Jones et al. [9], GHCNv3.2.0 by Lawrimore et al. [10], and GISS by Hansen et al. [11] and Rohde et al. [12] during the five historical time periods, as shown in Figure 3 and Table 2. At a global scale (after IPCC, 2013) [60], the precipitation trends per decade were investigated by applying various datasets; the CRU TS 3.10.01 was used by Mitchell and Jones [21], GHCN V2 by Vose [22], GPCC V6 by Becker [23] and Smith et al. [24] in two past time horizons, as shown in Figure 4. In addition, according to the IPCC 2013 [60], Dai et al. [31] studied the record data for 925 gauging station across the globe on the largest rivers. Dai et al. [31] reported that the discharges in the 200 rivers showed statistically significant trends in the period of 1948-2004, with a downward trend in 45 rivers and upward trends in 19 rivers. Stahl et al. [61] analyzed the streamflow datasets of more than 400 small near-natural catchments in Europe to investigate the river discharge trends for the period of 1962-2004. The analyses of Stahl et al. showed negative streamflow trends in the southern and eastern regions and positive trends elsewhere. The temporal trends of natural river discharge varied with the period of study. The comprehensive analyses during the 20th century IPCC Report (2013) led to low confidence in an increasing trend of global river discharge [60]. In addition, in this 
study, we present streamflow trend analyses to improve our understanding of the hydrological regime in the upstream area of the ungauged Kofarnihon River Basin against the background of the variability of the river regime of other rivers in other regions across the globe.

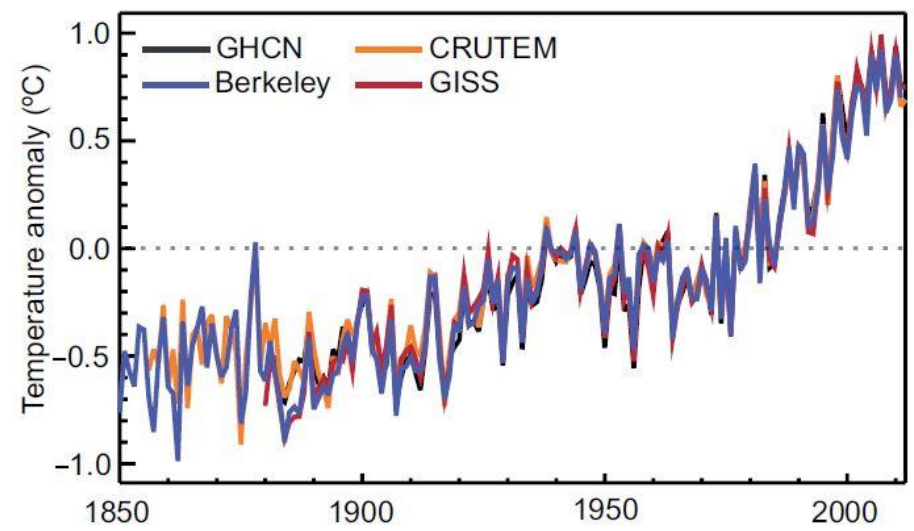

Figure 3. The global annual mean land-surface air temperature anomalies from the four datasets of Berkeley, CRUTEM, GHCN, and GISS, compared to the period of 1961-1990 (Source: IPCC report, $2013[60])$.

Table 2. The seasonal temperature trends and the original Mann-Kendall test in the Kofarnihon River Basin, Central Asia.

\begin{tabular}{|c|c|c|c|c|c|c|}
\hline Climate Station & Anzob & Hushyori & Faizobod & Dushanbe & Isambay & Shaartuz \\
\hline Elevation (m) & 3373 & 1361 & 1215 & 800 & 563 & 378 \\
\hline Period & \multicolumn{6}{|c|}{ 1951-2012 } \\
\hline January & $-1.756^{*}$ & +0.164 & +0.523 & +1.015 & +1.483 & $+1.713^{*}$ \\
\hline February & -1.051 & +0.03 & +0.741 & +0.286 & +0.583 & +0.207 \\
\hline March & -0.912 & +1.107 & $+1.853 *$ & $+2.011 *$ & $+2.061 *$ & +1.593 \\
\hline April & +0.985 & $+2.978 * * *$ & $+2.559 * *$ & $+2.595 * *$ & $+2.638 * *$ & $+2.000 *$ \\
\hline May & +0.359 & +0.694 & +1.137 & +1.252 & +1.252 & +1.574 \\
\hline June & 1.951 * & +0.48 & $+1.679 *$ & $+2.013 *$ & +1.618 & $+4.142^{* * *}$ \\
\hline July & +0.401 & -1.089 & -0.48 & $+2.469 *$ & +0.693 & $+2.569 *$ \\
\hline August & $+2.037^{* *}$ & +0.0001 & +0.657 & $+5.015^{* * *}$ & +0.894 & $+4.076^{* * *}$ \\
\hline September & $+1.958 *$ & +0.500 & +0.657 & $+4.346^{* * *}$ & +1.758 * & $+4.033^{* * *}$ \\
\hline October & +1.526 & +0.420 & +0.900 & $+3.027^{* *}$ & +1.465 & $+2.875 * *$ \\
\hline November & +1.641 & $+1.994^{* *}$ & +1.525 & $+2.200 *$ & $+2.352 *$ & +2.540 * \\
\hline December & -1.118 & -0.237 & +0.316 & +1.616 & +0.748 & +0.912 \\
\hline Period & \multicolumn{6}{|c|}{ 1979-2012 } \\
\hline January & $-2.567^{*}$ & -0.356 & -0.282 & -0.104 & +1.350 & +1.305 \\
\hline February & -1.202 & +0.030 & +0.504 & +0.163 & +1.023 & +0.430 \\
\hline March & +0.519 & $+2.539 *$ & $+2.536^{*}$ & $+2.136^{*}$ & $+3.294^{* * *}$ & $+2.374 *$ \\
\hline April & +0.001 & $+1.959 *$ & +0.608 & +0.445 & $+1.721^{*}$ & +0.519 \\
\hline May & -0.015 & +0.891 & +0.341 & -0.386 & +0.519 & +0.222 \\
\hline June & +0.668 & +1.232 & +0.816 & -1.203 & +0.742 & +1.072 \\
\hline July & -1.483 & -0.386 & $-1.959 *$ & -2.420 * & +0.297 & -0.878 \\
\hline August & +1.173 & +1.635 & +0.134 & -0.460 & $+1.885 *$ & +1.591 \\
\hline September & +0.817 & $+2.186^{*}$ & +1.276 & -0.564 & +2.213 * & $+2.467^{*}$ \\
\hline October & +1.231 & $+1.708^{*}$ & +1.381 & -0.044 & $+2.240 *$ & $+2.003 *$ \\
\hline November & -0.875 & -0.030 & -1.320 & -1.483 & -0.015 & -0.163 \\
\hline December & $-2.790 * *$ & -1.217 & $-1.735 *$ & -1.143 & -1.142 & -1.113 \\
\hline
\end{tabular}




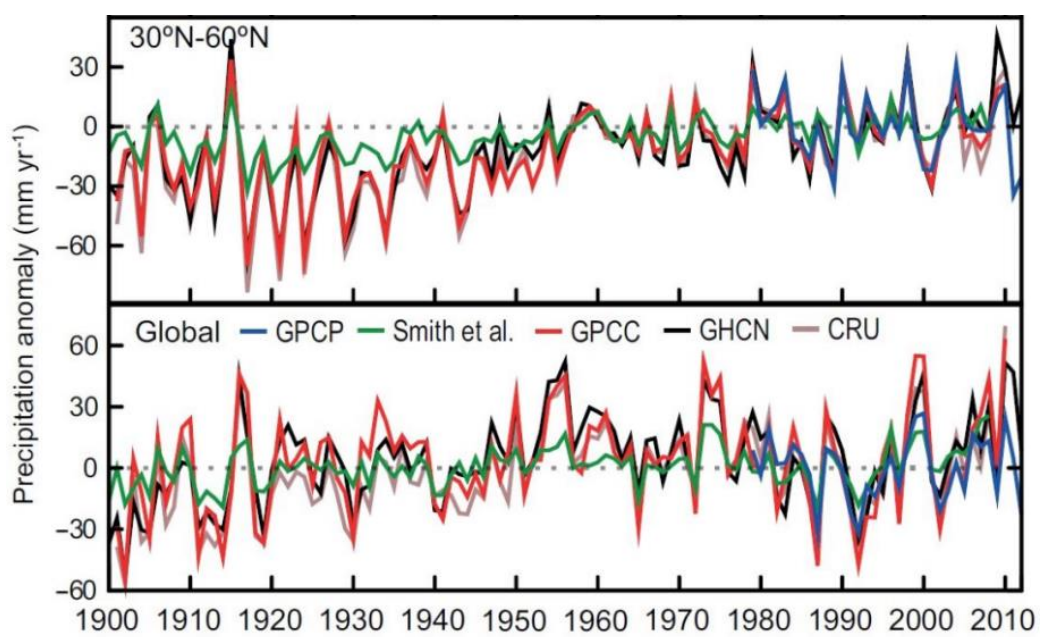

Figure 4. The mean annual precipitation anomalies over land areas for the globe and one latitudinal band from the five global precipitation datasets CRU, GHCN, GPCC, Smith et al. and GPCP compared to the period of 1981-2000 (Source: IPCC report, 2013 [60]).

\section{Methodology}

Globally, statistical and gridding methods have been widely used to estimate the long-term temperature, precipitation, and streamflow trends [62-64]. In this study, based on measured station data, the statistical methods of Mann-Kendall (MK) test, modified Mann-Kendall (MMK) test, and Sen's slope were applied to determine the trends in a long-term time series of temperature, precipitation, and river flow. To determine abrupt changes, the Pettitt's test was also used.

\subsection{Mann-Kendall (MK) Test}

The MK test is a non-parametric test for identifying trends in time series data [65]. Using linear regression, the trend rate $m_{1}$ is determined applying Equation (1):

$$
y=m_{1} x_{t}+c_{0}
$$

where $x$ indicates the temperature and precipitation for the periods of 1951-2012 and 1951-2008. Using a $t$-test, the significance of $m_{1}$ was verified. The positive and negative values of $m_{1}$ show increasing and decreasing trends of temperature, precipitation, and flow in particular time series [66]. Yue and Wang [67] reported that the strength of the trend depends on the magnitude of the trend, the sample size, the adjusted significance level, and the number of alterations over a time series. The MK test statistics (S) are determined by Equation (2):

$$
\begin{gathered}
S=\sum_{k=1}^{n-1} \sum_{j=k+1}^{n} \operatorname{sgn}\left(X_{j}-X_{k}\right), \\
\operatorname{sgn}\left(X_{j}-X_{k}\right)=\left\{\begin{array}{c}
\text { if }\left(X_{j}-X_{k}\right)>0,+1 \\
\text { if }\left(X_{j}-X_{k}\right)=0,0 \\
\text { if }\left(X_{j}-X_{k}\right)<0,-1
\end{array}\right\},
\end{gathered}
$$

where $n$ is the length of the dataset, $X_{j}$ and $X_{k}$ are the data values at times $j$ and $k$, and $\operatorname{sg} n$ is the sign function that takes on values of $-1,0$, and +1 . The resulting $t$ value of $S$ shows upward or downward trends in the climatic datasets:

$$
\operatorname{Var}(S)=\frac{n(n-1)(2 n+5)-\sum_{k=1}^{p} t_{k}\left(t_{k}-1\right)\left(2 t_{k}+5\right)}{18},
$$


where $p$ is the tied group, and $t_{k}$ is the number of observations in the $k$ th group. As determined by Equation (5), the (STS) standardized test statistic $\left(Z_{S}\right)$ can be determined by

$$
Z_{S}=\left\{\begin{array}{c}
\frac{S-1}{\sqrt{\operatorname{Var}(S)}}, S>0 \\
0, S=0 \\
\frac{S+1}{\sqrt{\operatorname{Var}(S)}}, S<0
\end{array}\right\},
$$

where $Z_{S}$ shows the significance of the trend. The STS is then applied to test the null hypothesis, $H_{0}$ if $Z_{s}>Z_{\alpha / 2}$, while $\alpha$ shows the confidence level. In this study, if a trend in the temperature, precipitation, or flow time series is statistically significant at a significance level of $\alpha=0.01$ (or $99 \%$ confidence intervals), $\alpha=0.05$ (or $95 \%$ confidence intervals), and $\alpha=0.1$ (or $90 \%$ confidence intervals). At a $1 \%, 5 \%$, and $10 \%$ significance level, the null hypothesis of no trend is rejected if $Z_{s}>1.45, Z_{s}>1.96$, and $Z_{s}>2.56$, respectively. The detailed explanation of the modified Mann-Kendall test is shown in Appendix A.

\subsection{Sen's Slope Test}

Using Sen's slope test, the magnitude of the trends over the time series was calculated. The slope of the pair of data " $n$ " was first calculated using Equation (6):

$$
Q=\frac{X_{j}-X_{k}}{j-k} \text { if } k<j,
$$

where $X_{j}$ and $X_{k}$ are the data values at times $j$ and $k$. The median of the " $n$ " values of $Q$ is Sen's estimator of slope. The positive and negative values of $Q$ present an increasing and a decreasing trend in the temperature, precipitation, and flow datasets. The slopes $(Q)$ of the " $n$ " values were ranked from low to high. Sen's estimator can be calculated using Equation (7):

$$
\text { Sen's estimator }=Q_{\frac{n+1}{2}} \text { if } n \text { is odd, } \frac{1}{2}\left[Q_{\frac{n}{2}}+Q_{\frac{n+1}{2}}\right] \text { if } n \text { is even. }
$$

\subsection{Pettitt's Test}

To detect a single change point in temperature, precipitation and flow time series with continuous data the Pettitt [52] approach is applied. Usually, when an adjacent change point exists in a series, the maximum value $K_{T}$ will be determined as the change point:

$$
\begin{gathered}
K_{T}=\max \left|U_{t, T}\right| \\
U_{t, T}=\sum_{i=1}^{t} \sum_{j=t+1}^{T} \operatorname{sgn}\left(X_{i}+X_{j}\right) .
\end{gathered}
$$

If $\left|U_{t, T}\right|$ increases with time $t$, then the sequence does not have a change point; conversely, if $\left|U_{t, T}\right|$ shows a decreasing trend against time $t$, then a change point occurred in the series. The change point of the series is located at $K_{T}$, provided that the statistic is significant. The significance probability of $K_{T}$ is approximated for $p \leq 0.05$ with

$$
p=2 \exp \left(\frac{-6 K_{T}^{2}}{T^{3}+T^{2}}\right)
$$

\section{Results}

Based on the long-term measured station data in the ungauged Kofarnihon River Basin, the trends and magnitudinal changes of monthly and annual temperature, precipitation, and streamflow were determined by applying the non-parametric Mann-Kendall, modified Mann-Kendall, and Sen's slope 
tests. We also used Pettitt's test to analyze the changes during the 1951-2008, 1951-2012, and 1979-2012 time periods. In this study, the availability of observational hydro-climatic measured data in the $\mathrm{KRB}$ and its utilization in regional analysis were essential to derive comprehensive outcomes of the hydro-climatic variability in recent decades. In addition, we presented the temperature, precipitation, and streamflow trend analyses from the IPCC report 2013 solely for demonstration purposes, as the period of our study in the KRB was the same as that in the IPCC report 2013 (Tables 3-6). In continental and global scale trend analyses most studies were performed based on gridded data, which has more uncertainty than observational data. The global trend analysis according to the IPCC report 2013 was described based on the datasets of CRUTEM, GHCNv3, GISS, and Berkeley for the temperature trend; CRUTS, GHCN V2, GPCC V6, and Smith et al. for the precipitation trends; and Dai et al. [31] and Stahl et al. [61] for the streamflow trends.

Table 3. Linear trend in global land surface air temperatures over two periods, 1951-2012 and 1979-2012 (IPCC, 2013).

\begin{tabular}{ccc}
\hline & Temperature Trend $\left({ }^{\circ} \mathbf{C}\right.$ Per Decade) & \\
\hline Dataset & Land Areas over the Globe & Land Areas over the Globe \\
$\mathbf{1 9 5 1 - 2 0 1 2}$ & $\mathbf{1 9 7 9 - 2 0 1 2}$ \\
\hline $\begin{array}{c}\text { Climatic Research Unit Temperature Anomalies } \\
\text { Over Land version 4 (CRUTEM4.1.1.0) [9] }\end{array}$ & $0.175 \pm 0.037$ & $0.254 \pm 0.050$ \\
Global Historical Climatology Network Version & $0.197 \pm 0.031$ & $0.273 \pm 0.047$ \\
3 (GHCNv3.2.0) [10] & $0.188 \pm 0.032$ & $0.267 \pm 0.054$ \\
Goddard Institute of Space Studies (GISS) [11] & $0.175 \pm 0.029$ & $0.254 \pm 0.049$
\end{tabular}

Table 4. Annual temperature trends per decade (T/D), Sen's slope, abrupt-point analysis, and original and modified Mann-Kendall (MK) tests for the trends (Z) in the Kofarnihon River Basin, Central Asia.

\begin{tabular}{|c|c|c|c|c|c|c|c|}
\hline \multirow[b]{2}{*}{$\begin{array}{l}\text { Climate } \\
\text { Station }\end{array}$} & & \multicolumn{6}{|c|}{$1951-2012,{ }^{\circ} \mathrm{C}$} \\
\hline & Abrupt & $\begin{array}{c}\mathrm{Z} \\
\text { (Modified) }\end{array}$ & $\begin{array}{c}\mathrm{Z} \\
\text { (Original) }\end{array}$ & T/D & $p$-Value & Slope & $\begin{array}{c}\text { Significance } \\
\text { Based on the } \\
\text { Modified MK Test }\end{array}$ \\
\hline Anzob & 2007 & 0.914 & 0.413 & 0.012 & 0.360 & 0.002 & NS \\
\hline Hushyori & 1998 & 2.473 & 1.385 & 0.067 & 0.013 & 0.006 & $* *$ \\
\hline Faizobod & 1976 & 6.078 & 2.229 & 0.122 & 0.000 & 0.012 & $* * *$ \\
\hline Dushanbe & 1976 & 7.593 & 4.610 & 0.253 & 0.000 & 0.024 & $* * *$ \\
\hline Isambay & 1996 & 6.046 & 3.608 & 0.192 & 0.000 & 0.017 & $* * *$ \\
\hline Shaartuz & 1978 & 9.997 & 4.574 & 0.228 & 0.000 & 0.022 & $* * *$ \\
\hline $\begin{array}{l}\text { Climate } \\
\text { Station }\end{array}$ & & \multicolumn{6}{|c|}{$1979-2012,{ }^{\circ} \mathrm{C}$} \\
\hline Anzob & 2007 & -1.713 & -0.978 & -0.185 & 0.086 & -0.017 & $*$ \\
\hline Hushyori & 1998 & 4.147 & 2.239 & 0.257 & 0.000 & 0.025 & $* * *$ \\
\hline Faizobod & 1996 & 0.755 & 0.400 & 0.051 & 0.450 & 0.003 & NS \\
\hline Dushanbe & 1990 & -0.771 & -0.252 & -0.049 & 0.440 & -0.003 & NS \\
\hline Isambay & 1996 & 6.836 & 3.528 & 0.367 & 0.000 & 0.036 & $* * *$ \\
\hline Shaartuz & 1997 & 5.431 & 2.283 & 0.216 & 0.000 & 0.024 & $* * *$ \\
\hline
\end{tabular}

The significance levels tested are ${ }^{* * *}$ for $p<0.001,{ }^{* *}$ for $p<0.01,{ }^{*}$ for $p<0.05$, NS for $p \geq 0.1$.

\subsection{Trend Analysis of the Seasonal Temperature in the Kofarnihon River Basin}

The seasonal temperature trends at the six climate stations during the 1951-2012 and 1979-2012 periods in the Kofarnihon River Basin are shown in Table 2. The results of the original MK test showed a significant increasing trend for the mean monthly temperature during the 1951-2012 period in spring (March, April, and May), summer (June, July, and August), and fall (September, October, and November) at the five climate stations, except for Anzob station, where a decreasing trend was observed in winter (December, January, and February). In the low-altitude areas, the change in the mean monthly temperature is somewhat complicated, particularly at the Dushanbe station. At this station, the mean monthly temperature showed an increasing trend during the 1951-2012 period in all 
months. The 1979-2012 period presented a decreasing trend over nine months, except for February, March, and April. The original MK test of the seasonal mean temperature for the periods of 1951-2012 and 1979-2012 demonstrated that in the Kofarnihon River Basin, the summer temperature trend significantly increased at high-altitudes and that the winter temperature trend significantly decreased during the 1951-2012 period. In the low-altitude areas, the spring and fall temperature trends increased, and the winter temperature decreased at all six stations during the 1979-2012 period. The findings of the winter cooling in our basin are in agreement with Li et al. [68] and Wang et al. [69]. The Eurasian winter cooling trend during the 1998-2012 period is caused internal atmospheric variability and constitutes an extreme climate event. Furthermore, the observed reduction in Artic sea ice enhances the probability of Eurasian winter and thus increases the probability of an extreme Eurasian winter cooling trend [68]. East Asia experienced more cold winters and significantly negative surface air temperature anomalies during the recent strong East Asian winter monsoon epoch spanning the period 2004-2012 [69]. Cooling has generally coincided with negative winter temperature trends in eastern Eurasia over the last two decades, possibly contributing to the observed regional cooling. Enhanced wintertime blocking activities around the Ural mountain region and the diminished Arctic sea ice concentrations are suggested to be the internal atmospheric processes responsible for this phenomenon and the external drivers for the recent re-amplification of the East Asian winter monsoon [69].

Table 5. The seasonal precipitation trend and original Mann-Kendall test in the Kofarnihon River Basin, Central Asia.

\begin{tabular}{ccccccc}
\hline Climate Station & Anzob & Hushyori & Faizobod & Dushanbe & Isambay & Shaartuz \\
\hline Elevation $(\mathrm{m})$ & 3373 & 1361 & 1215 & 800 & 563 & 378 \\
\hline Period & & \multicolumn{7}{c}{$1951-2008$} \\
January & $+3.173^{* *}$ & +0.322 & +1.000 & +0.402 & +0.503 & -0.503 \\
February & $+2.294^{*}$ & +0.288 & -0.215 & +0.59 & -0.409 & -0.101 \\
March & -0.349 & -1.322 & $-1.939^{*}$ & $-1.905 *$ & -0.745 & -0.436 \\
April & $-2.308^{*}$ & -0.631 & -1.368 & -1.583 & $-2.408^{*}$ & $-2.375^{*}$ \\
May & $-2.918^{* *}$ & -0.865 & -1.275 & -1.248 & $-2.086^{*}$ & $-2.449^{*}$ \\
June & $-2.650^{* *}$ & +0.329 & +0.262 & +0.684 & +1.016 & $+1.777^{*}$ \\
July & -0.859 & +0.819 & $+1.878^{*}$ & +0.666 & $+2.371 *$ & +0.845 \\
August & -0.845 & +1.309 & +0.504 & -0.345 & +0.954 & +1.079 \\
September & +1.288 & +1.556 & $+2.019 *$ & $+2.590 * *$ & -0.231 & $+2.135 *$ \\
October & -0.382 & +0.423 & -0.282 & +0.537 & +0.357 & +0.36 \\
November & +0.610 & -0.389 & -0.309 & -0.356 & -0.691 & +0.107 \\
December & $+3.173 * *$ & +0.322 & +1.000 & +0.402 & +0.503 & -0.503 \\
\hline
\end{tabular}

The significance levels tested are ${ }^{* *}$ for $p<0.01,{ }^{*}$ for $p<0.05$.

Table 6. Linear trend in the mid-latitude northern hemisphere $\left(30^{\circ} \mathrm{N}-60^{\circ} \mathrm{N}\right)$ and annual global land precipitation, 1951-2008 (IPCC, 2013).

\begin{tabular}{|c|c|c|}
\hline \multicolumn{3}{|c|}{ Precipitation Trends in mm yr ${ }^{-1}$ Per Decade, 1951-2008 } \\
\hline Dataset & $\begin{array}{l}\text { Land Areas over the Mid-Latitude } \\
\text { North Hemisphere }\left(30^{\circ} \mathrm{N}-60^{\circ} \mathrm{N}\right)\end{array}$ & Land Areas over the Globe \\
\hline Climatic Research Unit (CRU) TS 3.10.01 [21] & $1.13 \pm 2.01$ & $-2.12 \pm 3.52$ \\
\hline $\begin{array}{l}\text { Global Historical Climatology Network Version } \\
\qquad 2 \text { (GHCN V2) [22] }\end{array}$ & $1.39 \pm 1.98$ & $-2.77 \pm 3.92$ \\
\hline $\begin{array}{c}\text { Global Precipitation Climatology Centre } \\
\text { Version } 6 \text { (GPCC V6) [23] }\end{array}$ & $1.50 \pm 1.93$ & $-1.54 \pm 4.50$ \\
\hline Smith et al. [24] & $0.97 \pm 0.88$ & $0.68 \pm 2.07$ \\
\hline
\end{tabular}

\subsection{Trend Analysis of the Annual and Decadal Temperature}

We computed the temperature trends per decade during the 1951-2012 and 1979-2012 time periods, which correspond to the periods of the global temperature trends based on the trend per decade (T/D), as shown in Table 3. 
The results of the annual temperature trend per decade, the Sen's slope, the abrupt change detection, and the original and modified Mann-Kendall trend tests are shown in Table 4. The mean annual temperature trend showed an increasing trend during the 1951-2012 period. The highest temperature trends of $0.25^{\circ} \mathrm{C} /$ decade and $0.23^{\circ} \mathrm{C} /$ decade were observed at the Dushanbe and Shaartuz stations; the lowest of $0.01{ }^{\circ} \mathrm{C} /$ decade was found at Anzob, with $0.07^{\circ} \mathrm{C} /$ decade at Hushyori. According to the original and modified MK tests, the mean annual temperature showed an increasing trend during the 1951-2012 period, which is in line with the linear trend of the global land surface air temperature (Table 3). Since the 1930s, the mean annual temperatures have increased, and the average rate of variation has remained around $0.1^{\circ} \mathrm{C}$ per decade in Tajikistan [20]. For the five climate stations under study, the mean annual temperature showed a significant increasing trend during the 1951-2012 period, except for the Anzob station, where a non-significant trend was found. Anzob is located at the highest altitude compared to the other reference stations in the catchment.

The temperature trend per decade during the 1979-2012 period at all stations ranged from $0.36^{\circ} \mathrm{C} /$ decade to $-0.18^{\circ} \mathrm{C} /$ decade (Figure 5). Our results for the temperature trend per decade mostly correspond with the linear trends in global air surface temperature. There is a very small mismatch in the value ranges between our results in Table 4 and the datasets in Table 2. This small inconsistency in the ranges of the values can be ascribed to the use of observational data in the current study, which provide more accurate outcomes at the basin scale. Furthermore, the result of the original and modified MK tests showed a significant increase in the mean annual temperature trends at the Hushyori, Isambay, and Shaartuz stations, while a significant decreasing trend was found at the Anzob station during the 1979-2012 period. This discrepancy in the temperature trend could be attributed to the topography of the basin. The results of the Pettitt's test showed that a change in temperature from low to high-altitudes occurred in various periods. During the 1951-2012 time period, the change point at most stations appeared after 1976 and during the 1979-2012 period (after the 1990s), except for the Anzob station, where the change point occurred in 2007 during the 1951-2012 and 1979-2012 periods. The Pettit test results showed that an abrupt change in the high-altitude areas occurred later than that in the middle- and low-altitude areas of the Kofarnihon River Basin.

\subsection{Trend Analysis of the Seasonal Precipitation in the Kofarnihon River Basin}

The original MK test result of the seasonal precipitation trend during the 1951-2008 period in the Kofarnihon River Basin in Central Asia is shown in Table 5. The seasonal precipitation showed decreasing trends at all six climate stations in spring (March, April, and May). In winter (December, January, and February); however, we found an increasing trend for seasonal precipitation during the 1951-2008 period at most climate stations. Our results for seasonal precipitation reveal that in the high- and low-altitude areas, the spring precipitation significantly decreased; the winter precipitation significantly increased only in the high-altitude areas in the Kofarnihon River Basin in Central Asia.

\subsection{Trend Analysis of the Annual and Decadal Precipitation}

Table 6 presents a global analysis of the linear trend in the annual precipitation of the northern hemispheric and annual global land precipitation during the 1951-2008 period. In this study, the period of the annual and decadal precipitation trends was also chosen 1951-2008.

The results of the modified and original MK tests showed a decreasing trend in the annual and decadal precipitation during the 1951-2008 period. Among the six climate stations, the decreasing trend of the decadal precipitation $(\mathrm{P} / \mathrm{D})$ ranged from $-14.63 \mathrm{~mm}_{\text {year }}{ }^{-1}$ per decade to $-4.76 \mathrm{~mm}$ year $^{-1}$ per decade (Figure 6). The negative P/D trend in the Kofarnihon River Basin was stronger (Table 7) compared to the indications of the global analyses of the northern hemisphere and the global land areas (Table 6). The modified MK test presented a significant decreasing trend in the annual precipitation solely in the low-altitude areas, such as the Isambay and Shaartuz stations, while a non-significant trend was found in the high-altitude areas. The results of the Pettitt's test showed the change point to occur in 1994 at the Anzob station during the 1951-2008 time period. During this period, the precipitation 
changes at the Faizobod and Shaartuz stations occurred in 1999, while at the Hushtori, Dushanbe, and Isambay stations, the precipitation change occurred in 1969. The Pettitt's test results demonstrated that in this mountainous area, the earlier changes occurred in the low-altitude areas. This change could be attributable to the earlier effects of climate change on the low-altitude areas of the mountainous Kofarnihon River Basin in Central Asia.
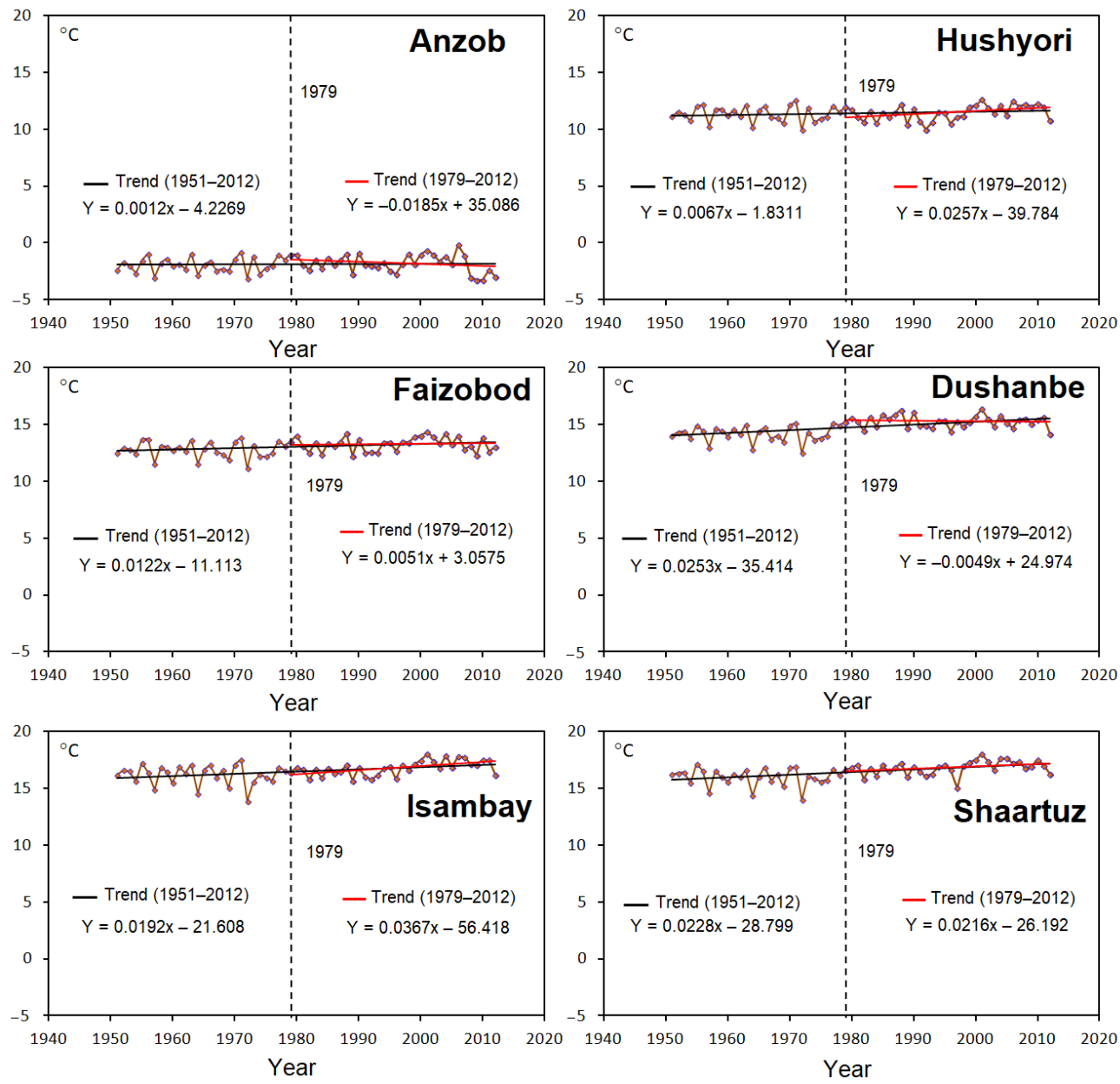

Figure 5. Inter-annual variability and trends of annual temperature during the 1951-2012 time period in the Kofarnihon River Basin, Central Asia.

Table 7. The annual precipitation trend, the precipitation per decade (P/D), the Sen's slope, the abrupt-point analysis, and the original and modified Mann-Kendall (MK) tests for the trends (Z) in the Kofarnihon River Basin, Central Asia.

\begin{tabular}{cccccccc}
\hline & \multicolumn{7}{c}{ 1951-2008, mm } \\
\cline { 2 - 7 } $\begin{array}{l}\text { Climate } \\
\text { Station }\end{array}$ & Abrupt & $\begin{array}{c}\text { Z } \\
\text { (Modified) }\end{array}$ & $\begin{array}{c}\mathbf{Z} \\
\text { (Original) }\end{array}$ & P/D & $p$-Value & Slope & $\begin{array}{c}\text { Significance } \\
\text { Based on the } \\
\text { Modified MK Test }\end{array}$ \\
\hline Anzob & 1994 & -1.661 & -0.765 & -4.759 & 0.096 & -0.554 & NS \\
Hushyori & 1969 & -1.033 & -0.328 & -12.894 & 0.301 & -0.928 & NS \\
Faizobod & 1999 & -1.314 & -0.684 & -14.636 & 0.188 & -1.141 & NS \\
Dushanbe & 1969 & -1.975 & -0.858 & -5.223 & 0.048 & -1.330 & $* *$ \\
Isambay & 1969 & -2.861 & -1.207 & -7.771 & 0.004 & -0.773 & $* * *$ \\
Shaartuz & 1999 & -3.104 & -1.388 & -8.944 & 0.002 & -1.031 & $* * *$ \\
\hline
\end{tabular}

The significance levels tested are ${ }^{* * *}$ for $p<0.001,{ }^{* *}$ for $p<0.01$, NS for $p \geq 0.1$. 

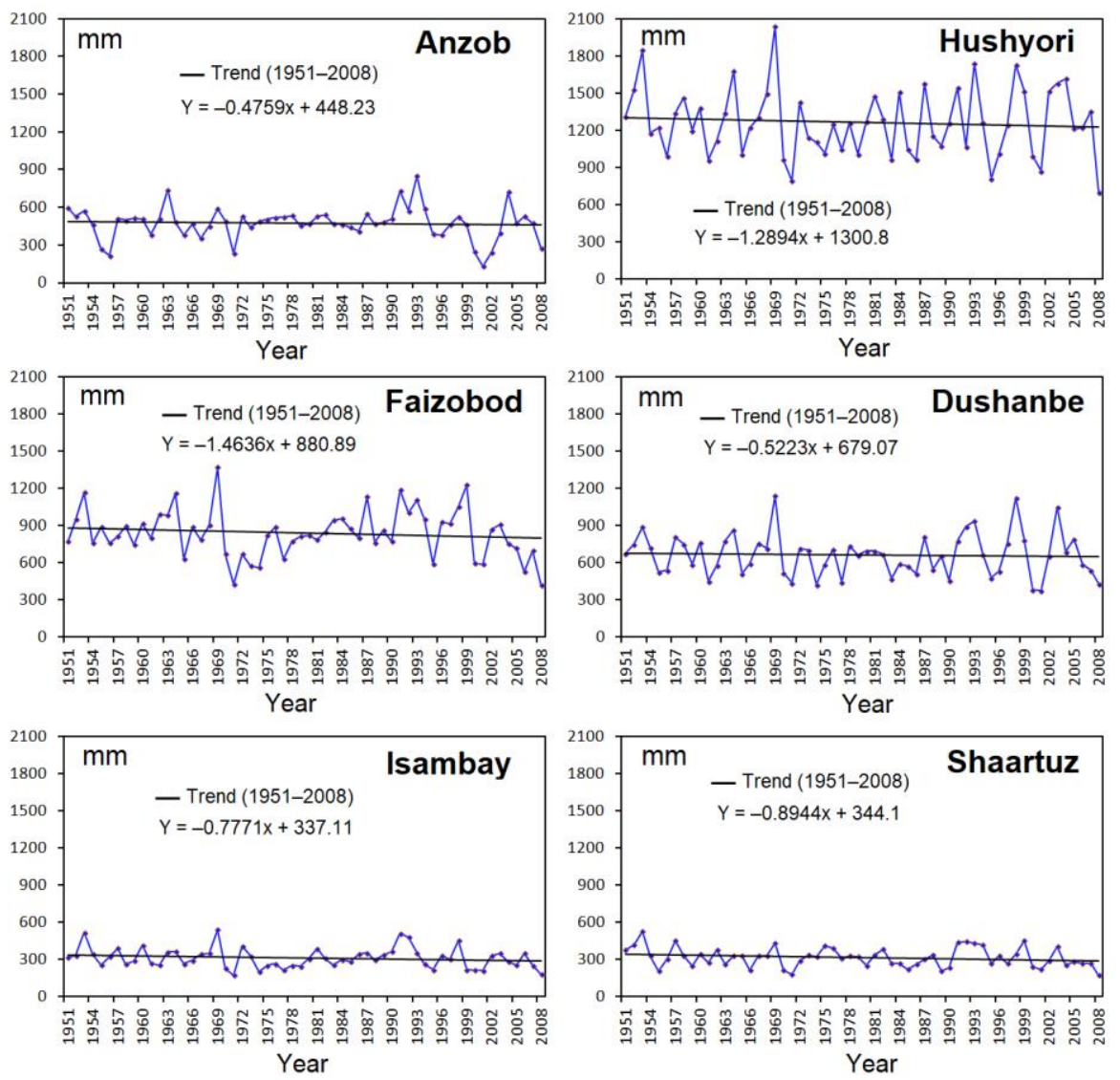

Figure 6. Inter-annual variabilities and trends of annual precipitation during the period of 1951-2008 in the Kofarnihon River Basin, Central Asia.

Based on the data from the six measured stations, the annual mean precipitation and annual mean air temperature were analyzed using Sen's slope (Figure 7). The mean air temperature increased from the upstream areas to the downstream areas of the KRB. The increased rate of air temperatures around the Dushanbe station was the highest in the KRB. This station is located in the capital city of Tajikistan, where urban built-up land is the main land use type near the station. The increased rate of annual precipitation in the KRB increased gradually from upstream areas to downstream areas. The annual precipitation decreased, and the annual mean air temperature increased, throughout the KRB.

\subsection{The Trend Analysis of the Seasonal Streamflow in the Kofarnihon River Basin}

The seasonal streamflow trend analysis was performed in the Varzob River based on the Dahana discharge station data for the 1951-2012 and 1979-2012 periods, as shown in Table 8. The Varzob River is an upstream and northwest tributary of the Kofarnihon River Basin. The results of the original MK test showed an increasing trend in the mean monthly streamflow in winter, spring, and summer, while the summer streamflow presented a significant increasing trend during the 1951-2012 period. The summer and spring streamflow showed an increasing trend, and the fall and winter streamflow indicated a decreasing trend during the 1979-2012 period. Our results show that in spring, the mean monthly streamflow significantly increased, and the fall streamflow significantly decreased, during the 1951-2012 and 1979-2012 periods in the upstream area of the KRB. 

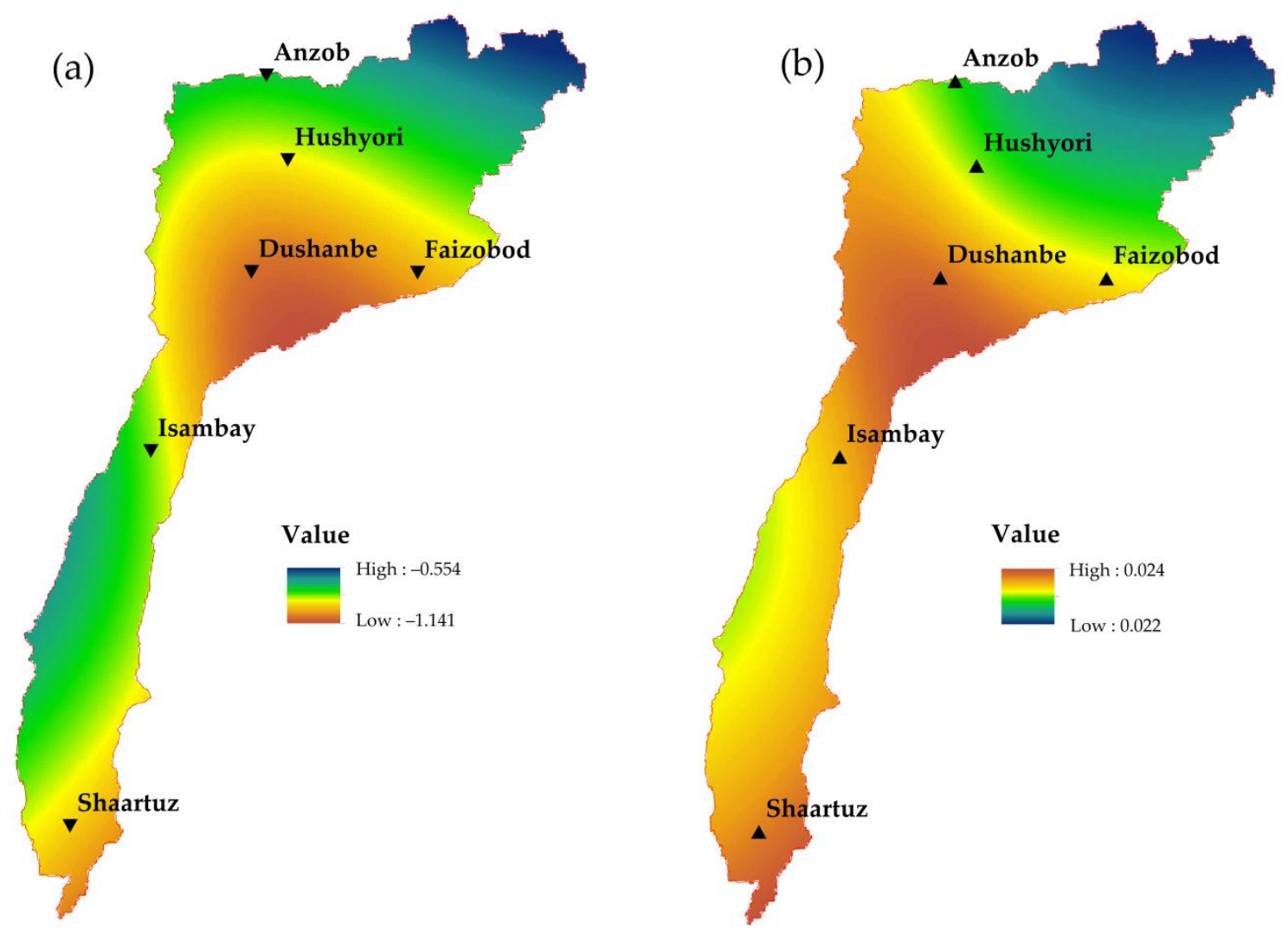

Figure 7. Sen's slope of (a) the annual mean precipitation and (b) annual air temperature in the Kofarnihon River Basin, Central Asia.

Table 8. The seasonal streamflow trends and the original Mann-Kendall test in the Kofarnihon River Basin, Central Asia.

\begin{tabular}{ccc}
\hline Discharge Station & \multicolumn{2}{c}{ Dahana } \\
\hline Elevation $(\mathrm{m})$ & \multicolumn{2}{c}{$\mathbf{1 2 9 5}$} \\
\hline Period & $\mathbf{1 9 5 1 - 2 0 1 2}$ & $\mathbf{1 9 7 9 - 2 0 1 2}$ \\
\hline January & +1.082 & -1.246 \\
February & $+1.841^{*}$ & -0.104 \\
March & +1.318 & +1.393 \\
April & $+1.877^{*}$ & +1.231 \\
May & $+1.853^{*}$ & +1.618 \\
June & +1.094 & +1.038 \\
July & +0.614 & +0.638 \\
August & -0.559 & +0.445 \\
September & -0.516 & -0.193 \\
October & $-2.375 *$ & $-2.654 * *$ \\
November & -0.735 & $-1.839 *$ \\
December & +0.261 & -1.306 \\
\hline
\end{tabular}

The significance levels tested are ${ }^{* *}$ for $p<0.01,{ }^{*}$ for $p<0.05$.

\subsection{Trend Analysis of the Annual Streamflow in the Kofarnihon River Basin}

The modified MK test showed a significant increasing trend for the annual streamflow in the upstream areas of the KRB during the 1951-2012 and 1979-2012 time periods. Increased flow upstream can be ascribed to the rapidly melting snow and ice caused by the continuously increasing air temperature. The large mass of water formed in the Varzob River experiences little demand during the growing season because the mountainous terrain in which the river flows does not have fertile valley 
plots of land. The water formed from the Varzob River almost completely flows downstream of the Kofarnihon River. In the downstream area of the KRB, the annual streamflow showed a decreasing trend according to Lobanova et al. This discrepancy indicates that, over time and space, anthropogenic activities have strictly disturbed the water distribution in the middle and downstream areas of the KRB. The decreasing trend of the annual streamflow in the downstream areas of the KRB is attributed to the increased water use with rapid population growth and the degradation of land under irrigation. Most of the populated cities are located in the middle and downstream areas, such as the capital city of Tajikistan-Dushanbe and the city of Vahdat, along with several well-populated districts in the territory of the KRB. The large-scale water intake and water consumption from the river occurs in the middle and downstream portions of the river. In the upstream areas of the KRB, the streamflow change point according to the Pettitt's test result occurred in 1991 during the 1951-2012 and 1979-2012 periods, as shown in Table 9 and Figure 8.

Table 9. The annual flow trends, the Sen's slope, the abrupt-point analysis, and the modified and original Mann-Kendall (MK) tests for trends (Z) in the Kofarnihon River Basin, Central Asia.

\begin{tabular}{ccc}
\hline Discharge Station & \multicolumn{2}{c}{ Dahana } \\
\hline Statistics $\backslash$ Period & $\mathbf{1 9 5 1 - 2 0 1 2}$ & $\mathbf{1 9 7 9 - 2 0 1 2}$ \\
\hline Abrupt & 1991 & 1991 \\
Z (modified) & 3.671 & 4.259 \\
Z (original) & 1.543 & 1.364 \\
$p$-value & 0.001 & 0.000 \\
Slope & 0.125 & 0.168 \\
Significance based on the modified MK test & $* * *$ & $* * *$ \\
\hline
\end{tabular}

The significance levels tested are ${ }^{* * *}$ for $p<0.001$
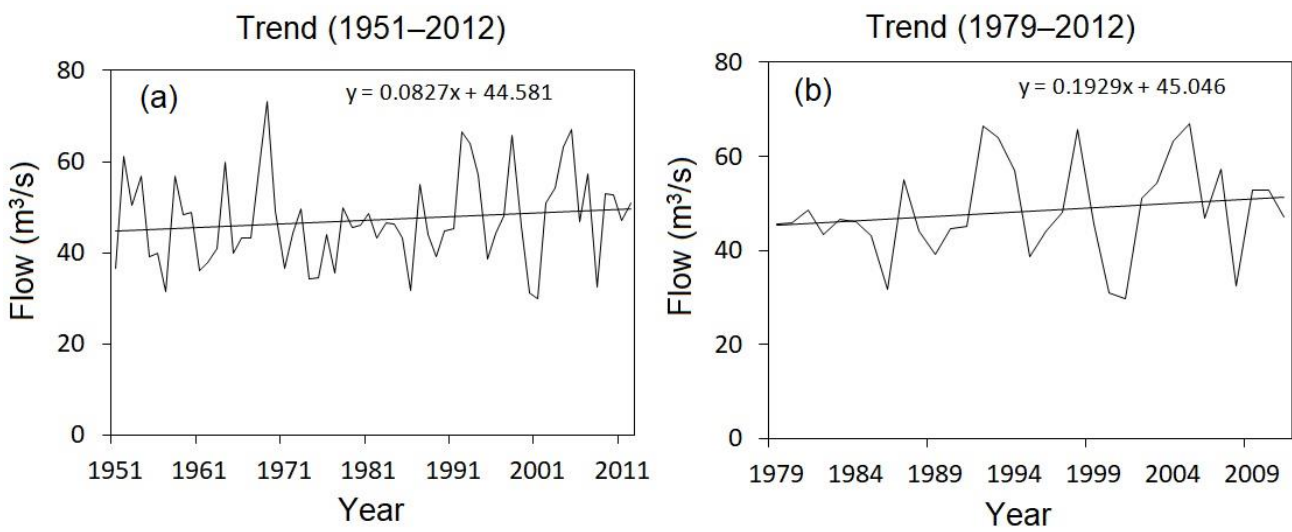

Pettitt test (1951-2012)
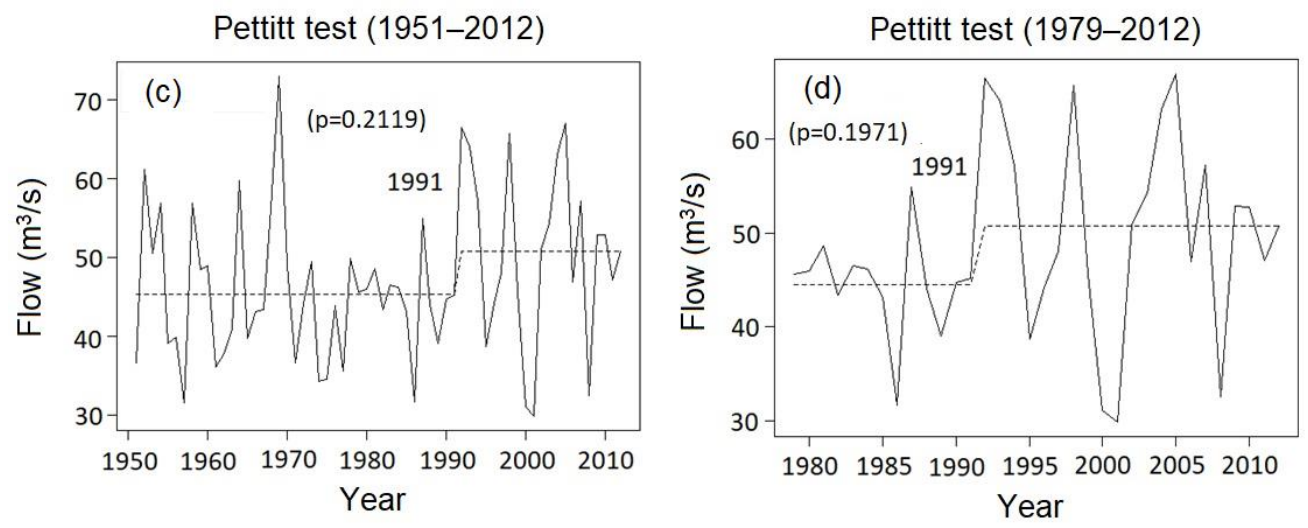

Figure 8. The annual flow trends during the (a) 1951-2012 and (b) 1979-2012 periods and the Pettitt's test during the (c) 1951-2012 and (d) 1979-2012 periods at the Dahana discharge gauging station in the upstream region of the Kofarnihon River Basin. 
The long-term observation data in the KR showed that the annual runoff of the river is $30-50 \mathrm{l} / \mathrm{s}$ per $\mathrm{km}^{2}$. The flooding period in this river starts at the end of March and the beginning of April, while the duration of this period depends on the snow cover and the water reserves in the snow. Peak floods occur in the May-June months. The reserves of the seasonal snow cover deplete in the month of July and begin to melt many small glaciers, depending on the warm air temperature in the summer season. The duration of the flooding is 160-180 days, and the increase in flooding waves lasts $60-80$ days.

The glaciers and snow cover significantly affect the water cycle and flow process of the KR; these processes can be significantly changed by climatic variation. Using field observations, we observed that the territory of the Anzob climate station is covered by snow for a period of eight months each year. The long-term data analysis of the snow-fed and glacier-fed river showed a constantly increasing trend of the streamflow in the upstream tributaries of the KRB during the 1951-2012 and 1979-2012 time periods. The result of the Pettitt's test showed that abrupt changes in streamflow occurred in 1991 in the upstream areas of the KRB during the 1951-2012 and 1979-2012 periods. We conclude that the increasing streamflow in the upstream regions of the KRB may be attributable to an increase in the snow and glaciers melting in the basin, which is influenced by the continuously increasing air temperature in the region. Studying the recent changes in the water cycle and flow regime of the Kofarnihon River is essential for Tajikistan, which uses water from the KR for drinking, irrigation, and generating electricity. It is also important for downstream countries, such as Uzbekistan and Turkmenistan, to adapt their national agricultural strategies to anomalous hydro-climatic conditions.

\section{Discussion}

The Kofarnihon River is the one of the northwest tributaries of the Amu Darya River. The climate of the basin is continental under the influence of westerly wind, leading to significant seasonal changes in temperature and precipitation [20]. These changes are due to the mountainous topography of the basin, which has a very high local contrast $[1,70]$. The mountainous area of this basin is the most vulnerable territory in Central Asia to hydro-climatic changes [2]. The tributaries of the Amu Darya River, such as the Panj River, Vakhsh River, and Kofarnihon River, are characterized by a seasonal cycle of river flow; the streamflow increases rapidly with the beginning of the melting period in March and April, the maximum river flow occurring in the summer season [71]. The present study examined the recent trends of the decadal, annual, and seasonal temperature, precipitation, and streamflow during the 1951-2012 and 1979-2012 time periods in the Kofarnihon River Basin in Central Asia.

Our results for the MK test revealed that the summer temperature trend significantly increased, and the winter temperature trend significantly decreased, during the 1951-2012 period in the high-altitude regions of the KRB. In the low-altitude areas, the spring and fall temperature trends increased, and the winter temperature decreased, at all six stations during the 1979-2012 period. Our results for the seasonal temperature trends also support the findings of Mannig et al. [17], who reported that the climate change signal of temperature is the largest in winter in the mountainous terrains of Central Asia. Piao et al. [33] reported that a reduction in the warming trend mostly occurred in the winter in the northern hemisphere. Similar results were presented by Pachauri et al. [72] for the global winter temperature trends during recent decades. Further, Li et al. [68] and Wang et al. [69] confirmed that in the Eastern Asia, the winter temperature decreased during the 1998-2012 and 2004-2012 periods. The decreasing probability of an extreme Eurasian winter temperature trend could be attributed to a reduction in Arctic sea ice enhancing the probability of Eurasian winters [68]. In this study, the mean annual temperature trend mostly showed an increasing trend during the 1951-2012 and 1979-2012 periods. These findings are in line with the results Chevallier et al. [19], who confirmed that the overall homogeneous trend of temperature increased in the mountainous region of Tajikistan. Aalto et al. [20] noted that since the 1930s, the mean annual temperatures have increased in Tajikistan. Giese et al. [14] and Christensen et al. [15] demonstrated that Central Asia has faced above-average global warming since the 1950s; the mean temperature increased by $1.2-2.1^{\circ} \mathrm{C}$, and during the 20th century, it increased by $1-2{ }^{\circ} \mathrm{C}$. Our findings also agree with the global land surface air temperature 
trends shown in Tables 3 and 4 [9-12]. The climate changes in Tajikistan are mostly limited by a variety of topographical situations due to adiabatic processes [73]. The temperature changes are likely influenced by other factors, such as solar radiation and cold-air drainage in mountainous terrains [74]. Another possible cause of the rising temperatures in the Kofarnihon River Basin could be the increasing concentration of aerosols and greenhouse gases in the regional atmosphere. Xin et al. [75] reported that over China and Central Asia, a rising trend in the concentration of aerosols in the atmosphere could cause a substantial increase in temperature. Bollasina et al. [76] confirmed that in Asia, the concentration of atmospheric aerosols has increased steadily. Similarly, Folini et al. [77] reported that aerosol emissions in the 20th century increased in association with the enormous growth in population and industrialization.

Seasonal precipitation showed a decreasing tend in the spring season in both high- and low-altitude regions, while the winter precipitation presented a significant increasing trend in the high-altitude regions during the 1951-2008 period in the Kofarnihon River Basin in Central Asia. Similarly, a significant increasing trend of the winter precipitation was found by Chen et al. [28] and Song et al. [30] for the Central Asia region, where they defined an increasing trend during the 1930-2009, 1960-1991, and 1960-2013 time periods. Pendergrass et al. [78] reported that the global winter precipitation increased during the second half of the 20th century and attributed this increase to the role of increasing moisture counteracted by weakening circulation. Our results for the annual precipitation trend showed a decreasing trend over the catchment at all stations under study. This result for the annual precipitation follows the same statistical trends observed over Central Asia [27]. Li et al. [27] noted that in Central Asia, at the end of 20th century, there was a persistent decreasing trend in annual precipitation. Chen et al. [28] studied annual precipitation using the monthly gridded method of precipitation from the Climatic Research Unit (CRU) during the 1930-2009 period and concluded that, generally, precipitation increased over the past 80 years in the westerly circulation-dominated regions of arid Central Asia. According to Ahmed et al. [29], the modified Mann-Kendall trend test results showed a significant increasing trend in annual precipitation during the 1961-2015 period in the Yangtze River of the Qinghai-Tibetan Plateau. In the Asian region, these contradictions in our findings may be associated with the increasing concentration of anthropogenic absorbing aerosols and the westerly system $[76,77,79]$. Donat et al. reported that in the dry regions of the globe, precipitation strongly increased, while in wet regions, only small changes were observed over the period of 1951-2010 [25]. We revealed that the decreasing trend of the annual precipitation in the Kofarnihon River Basin in Central Asia was more significant during the 1951-2008 period compared to the same period in previous studies on the northern hemisphere and at global scales, where different datasets were applied by Mitchell et al. [21], Vose et al. [22], Becker et al. [23], and Smith et al. [24] (Tables 6 and 7).

The Varzob River is one of the main tributaries and upstream of the Kofarnihon River. In this study, a trend analysis was performed based on the long-term streamflow data from the Dahana discharge station of the Varzob River. The seasonal streamflow trend in the upstream area of the KRB showed an increasing trend in spring and summer but a decreasing trend in fall and winter. In spring, the streamflow showed a significant increasing trend during the 1951-2012 period. Our results for the streamflow trend upstream of the KR contradicts the trend of the streamflow in the downstream areas of the KR, which was studied by Lobanova et al., who reported that the flow decreases in winter and fall; however, in spring, the flow increases and does not change during the summer season in the downstream portion of the KR [38]. Highly-populated cities of Tajikistan are located in the middle stream and downstream areas of the KRB, where the drinking and irrigating land use of water from the KR decreased the water availability downstream. Previous studies on the Yangtze River in Asia by Piao et al. [33] and Pachauri et al. [72] described an increasing trend of the streamflow in summer and a decreasing trend in fall. Jaweso et al. [80] reported that the monthly MK test exhibited a significant decreasing trend of the streamflow in the dry season and a significant increasing trend in the wet season during the 1980-2008 period in the Upper Omo-Ghibe River Basin in Ethiopia. The results of the modified MK test showed a significant increasing trend of the annual streamflow during the 
1951-2012 and 1979-2012 periods in the upstream areas of the Kofarnihon River. Our results of the annual streamflow trends agree with the results of previous studies that addressed the hydrological regime variations of the main rivers in Central Asia [34,38,81]. Shen et al. [35] noted that the MK test trend showed a significant increasing trend in the annual streamflow in four glacierized basins (Toxkon, Kunmalik, Kaidu and Huangshuigou) in the southern Tian Shan Mountains in Central Asia, especially during the spring and winter months. Zhang et al. [82] confirmed that the MK test results of the annual streamflow between the 1970s and the 1990s indicate a decreasing trend in the Yarlung Zangbo River in the Qinghai-Tibetan Plateau in Central Asia. Further, the MK trend test exhibited a significant decreasing trend of the annual streamflow in the rain-fed Yihe River in the central part of China during 1960-2008 [61]. Piao et al. reported a decreasing trend of the streamflow in the Yellow River in Asia since 1960s [33]. The rain-fed river basins showed that the streamflow increased in the Lanyang River Basin, Youluo River Basin, and Shangping River Basin. However, the streamflow decreased in the Keelung, Dahan, and Fengshan river basins during the 1980-2017 period in the East Asian regions [83]. Dai et al. [31] investigated the increasing and decreasing trends of the streamflow in different rivers across the globe and reported that in 45 rivers, the streamflow trend increased, while in 19 rivers, the streamflow decreased. The IPCC report 2013 noted that confidence is low for an increasing trend in global river discharge during the 20th century [60]. However, Rashid et al. [37] confirmed that the glacier-fed and snow-fed Lidder and Sindh rivers in the Himalayan Mountains exhibited a statistically significant depletion in their streamflow during the 1962-2018 period. According to Hooke [6] and Schaefli et al. [4], an increasing flow in mountainous rivers can be mostly attributed to global warming, which causes severe snowmelt and the retreat of glaciers. The Kofarnihon River in this study is a snow-fed and glacier-fed river; thus, these increases in summer water flow can be ascribed to the influence of global warming on the rapid melting of snow and ice.

The trends of hydro-climatic variables, such as temperature, precipitation, and streamflow, were studied in the mountainous KRB of Central Asia. We conclude that the mean annual temperature showed an increasing trend, while the annual precipitation showed a decreasing trend. The annual mean streamflow trends upstream showed an increasing trend during the 1951-2012 and 1979-2012 periods. In addition, this study revealed that in the mountainous region of the KR, the streamflow mostly depends on snowmelt and glacial melt, not rainfall. This indicates that climate warming in this mountainous area accelerated the melting of snow and glaciers, which caused an increase in river discharge. The use of hydro-climatic trend analysis based on observational data at the basin scale is essential for local agronomists, hydropower engineers, and decision makers to develop new strategies for anomalous hydro-climatic conditions. Further investigations could focus on combining the trend analysis of observational data with global climate model (GCM) data coupled with a hydrological model to predict the impacts of climate change and anthropogenic activities on water resources in the KRB.

\section{Conclusions}

In this study, the trends, abrupt changes, and periods of annual and seasonal temperature, precipitation, and streamflow series were analyzed. We applied non-parametric Mann-Kendall, modified Mann-Kendall and Sen's slope tests to monthly and annual hydro-climatic variables to determine the trends and magnitudinal changes in the Kofarnihon River Basin in Central Asia. We also used Pettitt's test to analyze the changes during the 1951-2012 and 1979-2012 time periods. The following conclusions can be summarized from the above analysis results.

(1) The mean monthly temperature showed a significant increasing trend in spring, summer, and fall at the five climate stations, except for Anzob station, where we found a decreasing trend in winter during the 1951-2012 period. The seasonal mean temperature indicated that in the high-altitude areas of the KRB, the summer temperature trend significantly increased, and the winter temperature trend decreased. The mean annual temperature showed an increasing trend, with the highest trends of $0.25{ }^{\circ} \mathrm{C} /$ decade and $0.23{ }^{\circ} \mathrm{C} /$ decade at the Dushanbe and Shaartuz 
stations, respectively; the lowest of $0.01^{\circ} \mathrm{C} /$ decade and $0.07^{\circ} \mathrm{C} /$ decade was found at the Anzob and Hushyori stations. The change points mainly occurred in the 1970s and 1990s for all stations, except for Anzob station, where the change point appeared in 2007. The Pettitt's test results showed that the abrupt changes in the high-altitude areas occurred later than those in the middleand low-altitude areas in the KRB.

(2) The seasonal precipitation exhibited decreasing trends at all six climate stations in spring, while an increasing trend was observed in winter at most climate stations during the 1951-2008 period. Our results for the seasonal precipitation showed a significant decreasing trend in spring and a significant increasing trend in winter in the high-altitude areas of the KRB. The annual precipitation trend at all stations continuously decreased over the basin, with the highest negative trend of $-14.63 \mathrm{~mm}$ year ${ }^{-1}$ per decade observed at the Faizobod station and the lowest of $-4.76 \mathrm{~mm}$ year $^{-1}$ per decade observed at the Anzob station. Due to their different natural topography and geographical locations, the different stations showed different results for these abrupt changes. Precipitation change points appeared in 1999 at the Faizobod and Shaartuz stations and in 1969 at the Hushtori, Dushanbe, and Isambay stations. At the high-altitude station of Anzob, the change point occurred in 1994. Earlier changes in precipitation were detected in the low-altitude regions of the KRB. These changes might be attributable to the earlier effects of climate change on the low-altitude areas of the mountainous KRB in Central Asia.

(3) The mechanism of change for the monthly streamflow upstream of the KRB is different in different time periods. The winter streamflow exhibited a significant increasing trend during the 1951-2012 period, while during the 1979-2012 period, the winter streamflow exhibited a significant decreasing trend. The original MK test results showed that the mean monthly streamflow significantly increased in spring and summer seasons, while the streamflow trend significantly decreased in fall and winter. The modified MK test result exhibited a significant increasing trend in the annual streamflow in the upstream of the KRB. The increased streamflow in the spring and summer seasons in the snow-fed and glacier-fed mountainous KRB is attributed to global warming, which causes severe melting of the snow and ice. We detected change points in the upstream flow in 1991 during both the 1951-2012 and 1979-2012 periods.

This study analyzed only the hydro-climatic spatiotemporal variability and did not consider the impact of anthropogenic activities. In the future, relevant indicators should be selected for further study, and the impact of anthropogenic activities should be analyzed. We revealed that the hydro-climatic variability in the upstream areas of the KRB impacts downstream water fluctuations. Our findings in this study will provide a scientific theoretical basis for water issues under ongoing climate change and help us to improve the water resources management in the KRB of Central Asia.

Author Contributions: All authors were involved in the intellectual elements of this paper. X.C., A.G., and T.L. designed the research. A.G. conducted the research and wrote the manuscript. N.G. and S.S. helped in the data arrangement, while R.D. helped in the data analysis. All authors have read and agreed to the published version of the manuscript.

Funding: This research was funded by the Strategic Priority Research Program of the Chinese Academy of Sciences, the Pan-Third Pole Environment Study for a Green Silk Road (Grant No. XDA20060303), the International Cooperation Project of National Natural Science Foundation of China (Grant No. 41761144079), the Xinjiang Tianchi Hundred Talents Program (Grant No. Y848041), and the project of the research Center of Ecology and Environment in Central Asia (Grant No. Y934031).

Acknowledgments: The authors are thankful to the Ministry of Energy and Water Resources of the Republic of Tajikistan and the Agency of Hydrometeorology of the Committee for Environmental Protection under the Government of the Republic of Tajikistan for providing the data for this research.

Conflicts of Interest: The authors declare no conflict of interest. 


\section{Appendix A}

\section{Software Package, "Modifiedmk"}

The modified MK test introduced by Hamed and Rao [84] was employed to evaluate the trends of serial correlation data. Later, Yue et al. [85] introduced a nonparametric modified MK trend method, that is suitable for autocorrelated data based on the modified value in the variance of the test statistic. The accuracy of this modified test in terms of its empirical significance was found to be superior to the original Mann-Kendall trend test without any loss of power. The open-course library package named "modifiedmk" was developed in the R-language [86]. The "modifiedmk" package was applied to compute the nonparametric Mann-Kendall tests and all modified versions of the Mann-Kendall tests mentioned in the current research. The "modifiedmk" package is now freely available via the CRAN repository and Github version control platform [87]. Adjusted variance expression is computed as below, and $Z$ values are found from Equations (A1) and (A2) [85]:

$$
\begin{gathered}
V(S)=\operatorname{Var}(S) \times \frac{n}{n_{S}^{*}}=\frac{n(n-1)(2 n+5)}{18} \times \frac{n}{n_{s}^{*}} \\
\frac{n}{n_{s}^{*}}=1+\frac{2}{n(n-1)(n-2)} \times \sum_{i=1}^{n-1}(n-i)(n-i-2) \rho_{s}(i)
\end{gathered}
$$

where $n / n_{s}{ }^{*}$ shows a correction due to autocorrelation in the data, " $n$ " is the actual number of observations, and $\rho_{s}$ (i) is the autocorrelation of the observation ranks. The results of all MK, MMK, Sen's Slope, and Pettitt's tests were derived using the RStudio software, version 3.5.3.

\section{References}

1. Williams, M.; Konovalov, V. Central Asia Temperature and Precipitation Data, 1879-2003; National Snow and Ice Data Center: Boulder, CL, USA, 2008.

2. World Bank. Key Issues for Consideration on the Proposed Rogun Hydropower Project. Available online: http://www.worldbank.org/content/dam/Worldbank/Event/ECA/central-asia/ (accessed on 27 May 2018).

3. Dukhovniy, V.A.; Ziganshina, D.R.; Sorokin, A.G.; Sorokin, D.A.; Stulina, G.V.; Solodky, G.F.; Muminov, S.H.; Makhramov, M.Y.; Tilyavova, G.K.; Nazariy, A.M.; et al. The future of the Amu Darya River Basin in the Condition of Changing Climate. Interstate Commission for Water Coordination in Central Asia. Available online: www.cawater-infor.net/project/peer-amudarya/ (accessed on 18 May 2018).

4. Schaefli, B.; Manso, P.; Fischer, M.; Huss, M.; Farinotti, D. The role of glacier retreat for Swiss hydropower production. Renew. Energy 2019, 132, 615-627. [CrossRef]

5. Buytaert, W.; Célleri, R.; De Bièvre, B.; Cisneros, F.; Wyseure, G.; Deckers, J.; Hofstede, R. Human impact on the hydrology of the Andean páramos. Earth Sci. Rev. 2006, 79, 53-72. [CrossRef]

6. Hooke, R.L. Principles of Glacier Mechanics; Cambridge University Press: Cambridge, UK, 2019.

7. Xu, M.; Kang, S.; Wu, H.; Yuan, X. Detection of spatio-temporal variability of air temperature and precipitation based on long-term meteorological station observations over Tianshan Mountains, Central Asia. Atmos. Res. 2018, 203, 141-163. [CrossRef]

8. Solomon, S.; Manning, M.; Marquis, M.; Qin, D. Climate Change 2007-The Physical Science Basis: Working Group I Contribution to the Fourth Assessment Report of the IPCC; Cambridge University Press: Cambridge, UK, 2007; Volume 4.

9. Jones, P.; Lister, D.; Osborn, T.; Harpham, C.; Salmon, M.; Morice, C. Hemispheric and large-scale land-surface air temperature variations: An extensive revision and an update to 2010. J. Geophys. Res. Atmos. 2012, 117. [CrossRef]

10. Lawrimore, J.H.; Menne, M.J.; Gleason, B.E.; Williams, C.N.; Wuertz, D.B.; Vose, R.S.; Rennie, J. An overview of the Global Historical Climatology Network monthly mean temperature data set, version 3. J. Geophys. Res. Atmos. 2011, 116. [CrossRef]

11. Hansen, J.; Ruedy, R.; Sato, M.; Lo, K. Global surface temperature change. Rev. Geophys. 2010, 48. [CrossRef] 
12. Rohde, R.; Muller, R.; Jacobsen, R.; Muller, E.; Perlmutter, S.; Rosenfeld, A.; Wurtele, J.; Groom, D.; Wickham, C. A New Estimate of the Average Earth Surface Land Temperature Spanning 1753 to 2011. Geoinform. Geostat. Overv. 2013, 7, 2.

13. Cohen, J.L.; Furtado, J.C.; Barlow, M.; Alexeev, V.A.; Cherry, J.E. Asymmetric seasonal temperature trends. Geophys. Res. Lett. 2012, 39. [CrossRef]

14. Giese, E.; Mossig, I.; Rybski, D.; Bunde, A. Long-Term Analysis of Air Temperature Trends in Central Asia (Analyse langjähriger Zeitreihen der Lufttemperatur in Zentralasien). Erdkunde 2007, 61, 186-202. [CrossRef]

15. Christensen, J.H.; Hewitson, B.; Busuioc, A.; Chen, A.; Gao, X.; Held, R.; Jones, R.; Kolli, R.K.; Kwon, W.; Laprise, R. Regional climate projections. In Climate Change, 2007: The Physical Science Basis. Contribution of Working group I to the Fourth Assessment Report of the Intergovernmental Panel on Climate Change; Chapter 11; Cambridge University Press: Cambridge, UK, 2007; pp. 847-940.

16. Zhang, H.; Ouyang, Z.; Zheng, H.; Wang, X. Recent climate trends on the northern slopes of the Tianshan Mountains, Xinjiang, China. J. Mt. Sci. 2009, 6, 255-265. [CrossRef]

17. Mannig, B.; Müller, M.; Starke, E.; Merkenschlager, C.; Mao, W.; Zhi, X.; Podzun, R.; Jacob, D.; Paeth, H. Dynamical downscaling of climate change in Central Asia. Glob. Planet. Chang. 2013, 110, 26-39. [CrossRef]

18. Yao, J.; Chen, Y. Trend analysis of temperature and precipitation in the Syr Darya Basin in Central Asia. Theor. Appl. Climatol. 2015, 120, 521-531. [CrossRef]

19. Chevallier, P.; Pouyaud, B.; Mojaïsky, M.; Bolgov, M.; Olsson, O.; Bauer, M.; Froebrich, J. River flow regime and snow cover of the Pamir Alay (Central Asia) in a changing climate. Hydrol. Sci. J. 2014, 59, 1491-1506. [CrossRef]

20. Aalto, J.; Kämäräinen, M.; Shodmonov, M.; Rajabov, N.; Venäläinen, A. Features of Tajikistan's past and future climate. Int. J. Climatol. 2017, 37, 4949-4961. [CrossRef]

21. Mitchell, T.D.; Jones, P.D. An improved method of constructing a database of monthly climate observations and associated high-resolution grids. Int. J. Climatol. J. R. Meteorol. Soc. 2005, 25, 693-712. [CrossRef]

22. Vose, R.S.; Schmoyer, R.L.; Steurer, P.M.; Peterson, T.C.; Heim, R.; Karl, T.R.; Eischeid, J.K. The Global Historical Climatology Network: Long-Term Monthly Temperature, Precipitation, Sea Level Pressure, and Station Pressure Data; Carbon Dioxide Information Analysis Center: Oak Ridge, TN, USA, 1992. [CrossRef]

23. Becker, A.; Finger, P.; Meyer-Christoffer, A.; Rudolf, B.; Schamm, K.; Schneider, U.; Ziese, M. A description of the global land-surface precipitation data products of the Global Precipitation Climatology Centre with sample applications including centennial (trend) analysis from 1901-present. Earth Syst. Sci. Data 2013, 5, 71-99. [CrossRef]

24. Smith, T.M.; Arkin, P.A.; Ren, L.; Shen, S.S. Improved reconstruction of global precipitation since 1900. J. Atmos. Ocean. Technol. 2012, 29, 1505-1517. [CrossRef]

25. Donat, M.G.; Lowry, A.L.; Alexander, L.V.; O'Gorman, P.A.; Maher, N. Addendum: More extreme precipitation in the world's dry and wet regions. Nat. Clim. Chang. 2017, 7, 154-158. [CrossRef]

26. Xu, Z.; Gong, T.; Li, J. Decadal trend of climate in the Tibetan Plateau-Regional temperature and precipitation. Hydrol. Process. Int. J. 2008, 22, 3056-3065. [CrossRef]

27. Li, Z.; Chen, Y.; Fang, G.; Li, Y. Multivariate assessment and attribution of droughts in Central Asia. Sci. Rep. 2017, 7, 1316. [CrossRef]

28. Chen, F.; Huang, W.; Jin, L.; Chen, J.; Wang, J. Spatiotemporal precipitation variations in the arid Central Asia in the context of global warming. Sci. China Earth Sci. 2011, 54, 1812-1821. [CrossRef]

29. Ahmed, N.; Wang, G.; Booij, M.J.; Oluwafemi, A.; Hashmi, M.Z.-u.-R.; Ali, S.; Munir, S. Climatic Variability and Periodicity for Upstream Sub-Basins of the Yangtze River, China. Water 2020, 12, 842. [CrossRef]

30. Song, S.; Bai, J. Increasing winter precipitation over arid central Asia under global warming. Atmosphere 2016, 7, 139. [CrossRef]

31. Dai, A.; Qian, T.; Trenberth, K.E.; Milliman, J.D. Changes in continental freshwater discharge from 1948 to 2004. J. Clim. 2009, 22, 2773-2792. [CrossRef]

32. Stocker, T. Climate change 2013: The Physical Science Basis: Working Group I Contribution to the Fifth Assessment Report of the Intergovernmental Panel on Climate Change; Cambridge University Press: Cambridge, UK, 2014.

33. Piao, S.; Ciais, P.; Huang, Y.; Shen, Z.; Peng, S.; Li, J.; Zhou, L.; Liu, H.; Ma, Y.; Ding, Y. The impacts of climate change on water resources and agriculture in China. Nature 2010, 467, 43-51. [CrossRef] 
34. Kure, S.; Jang, S.; Ohara, N.; Kavvas, M.; Chen, Z. Hydrologic impact of regional climate change for the snowfed and glacierfed river basins in the Republic of Tajikistan: Hydrological response of flow to climate change. Hydrol. Process. 2013, 27, 4057-4070. [CrossRef]

35. Shen, Y.-J.; Shen, Y.; Fink, M.; Kralisch, S.; Chen, Y.; Brenning, A. Trends and variability in streamflow and snowmelt runoff timing in the southern Tianshan Mountains. J. Hydrol. 2018, 557, 173-181. [CrossRef]

36. Xu, M.; Han, H.; Kang, S. Modeling glacier mass balance and runoff in the Koxkar River Basin on the South Slope of the Tianshan Mountains, China, from 1959 to 2009. Water 2017, 9, 100. [CrossRef]

37. Rashid, I.; Majeed, U.; Aneaus, S.; Pelto, M. Linking the Recent Glacier Retreat and Depleting Streamflow Patterns with Land System Changes in Kashmir Himalaya, India. Water 2020, 12, 1168. [CrossRef]

38. Lobanova, A.; Didovets, I. Analysis of the Water Quality Parameters in the Amudarya River, Berlin, Germany. Available online: http://www.cawater-info.net/amudarya-knowledge-base/pdf/ (accessed on 5 February 2020).

39. Martinez, C.J.; Maleski, J.J.; Miller, M.F. Trends in precipitation and temperature in Florida, USA. J. Hydrol. 2012, 452, 259-281. [CrossRef]

40. Jha, M.K.; Singh, A.K. Trend analysis of extreme runoff events in major river basins of Peninsular Malaysia. Int. J. Water 2013, 7, 142-158. [CrossRef]

41. Sonali, P.; Kumar, D.N. Review of trend detection methods and their application to detect temperature changes in India. J. Hydrol. 2013, 476, 212-227. [CrossRef]

42. Tabari, H.; Somee, B.S.; Zadeh, M.R. Testing for long-term trends in climatic variables in Iran. Atmos. Res. 2011, 100, 132-140. [CrossRef]

43. Mann, H.B. Nonparametric tests against trend. Econom. J. Econom. Soc. 1945, 13, 245-259. [CrossRef]

44. Kendall, M.G. Rank Correlation Methods; Griffin: London, UK, 1975.

45. Tan, M.L.; Samat, N.; Chan, N.W.; Lee, A.J.; Li, C. Analysis of precipitation and temperature extremes over the Muda River Basin, Malaysia. Water 2019, 11, 283. [CrossRef]

46. Yagbasan, O.; Demir, V.; Yazicigil, H. Trend Analyses of Meteorological Variables and Lake Levels for Two Shallow Lakes in Central Turkey. Water 2020, 12, 414. [CrossRef]

47. Patakamuri, S.K.; Muthiah, K.; Sridhar, V. Long-Term Homogeneity, Trend, and Change-Point Analysis of Rainfall in the Arid District of Ananthapuramu, Andhra Pradesh State, India. Water 2020, 12, 211. [CrossRef]

48. Li, X.; Meshgi, A.; Babovic, V. Spatio-temporal variation of wet and dry spell characteristics of tropical precipitation in Singapore and its association with ENSO. Int. J. Climatol. 2016, 36, 4831-4846. [CrossRef]

49. Li, X.; Wang, X.; Babovic, V. Analysis of variability and trends of precipitation extremes in Singapore during 1980-2013. Int. J. Climatol. 2018, 38, 125-141. [CrossRef]

50. Theil, H. A rank-invariant method of linear and polynomial regression analysis. In Henri Theil's Contributions to Economics and Econometrics; Springer: Berlin, Germany, 1992; pp. 345-381.

51. Sen, P.K. Estimates of the regression coefficient based on Kendall's tau. J. Am. Stat. Assoc. 1968, 63, 1379-1389. [CrossRef]

52. Pettitt, A. A non-parametric approach to the change-point problem. J. R. Stat. Soc. Ser. C (Appl. Stat.) 1979, 28, 126-135. [CrossRef]

53. Xue, L.; Yang, F.; Yang, C.; Chen, X.; Zhang, L.; Chi, Y.; Yang, G. Identification of potential impacts of climate change and anthropogenic activities on streamflow alterations in the Tarim River Basin, China. Sci. Rep. 2017, 7, 8254. [CrossRef] [PubMed]

54. Mallakpour, I.; Villarini, G. A simulation study to examine the sensitivity of the Pettitt test to detect abrupt changes in mean. Hydrol. Sci. J. 2016, 61, 245-254. [CrossRef]

55. Farr, T.G.; Rosen, P.A.; Caro, E.; Crippen, R.; Duren, R.; Hensley, S.; Kobrick, M.; Paller, M.; Rodriguez, E.; Roth, L. The Shuttle Radar Topography Mission. Rev. Geophys. 2007, 45, 1-33. Available online: https://developers.google. com/earth-engine/datasets/catalog/USGS_SRTMGL1_003 (accessed on 11 March 2020). [CrossRef]

56. Arino, O.; Ramos Perez, J.J.; Kalogirou, V.; Bontemps, S.; Defourny, P.; Van Bogaert, E. Global Land Cover Map for 2009 (GlobCover 2009); European Space Agency: Paris, France; University College London: London, UK, 2012.

57. Food and Agriculture Organization. International Institute for Applied Systems Analysis; International Soil Reference and Information Centre; JRC: Harmonized World Soil Database (Version 1.2); FAO: Rome, Italy; IIASA: Laxenburg, Austria, 2012.

58. Central Asian Countries Geoportal of Tajikistan. Available online: http://www.geoportal-tj.org/index.php/ geology (accessed on 13 July 2020). 
59. Tajik Development Gateway in Russian. Available online: https://www.tajik-gateway.org/wp/geography/ flora/ (accessed on 13 July 2020).

60. Stocker, T.F.; Qin, D.; Plattner, G.-K.; Tignor, M.; Allen, S.K.; Boschung, J.; Nauels, A.; Xia, Y.; Bex, V.; Midgley, P.M. Climate Change 2013: The Physical Science Basis; Cambridge University Press: Cambridge, UK, 2013.

61. Stahl, K.; Tallaksen, L.M.; Hannaford, J.; Van Lanen, H. Filling the white space on maps of European runoff trends: Estimates from a multi-model ensemble. Hydrol. Earth Syst. Sci. 2012, 16, 2035-2047. [CrossRef]

62. Xu, S.; Qin, M.; Ding, S.; Zhao, Q.; Liu, H.; Li, C.; Yang, X.; Li, Y.; Yang, J.; Ji, X. The Impacts of Climate Variation and Land Use Changes on Streamflow in the Yihe River, China. Water 2019, 11, 887. [CrossRef]

63. Zeleňáková, M.; Purcz, P.; Blišt'an, P.; Vranayová, Z.; Hlavatá, H.; Diaconu, D.C.; Portela, M.M. Trends in Precipitation and Temperatures in Eastern Slovakia (1962-2014). Water 2018, 10, 727. [CrossRef]

64. Mu, X.; Wang, H.; Zhao, Y.; Liu, H.; He, G.; Li, J. Streamflow into Beijing and Its Response to Climate Change and Human Activities over the Period 1956-2016. Water 2020, 12, 622. [CrossRef]

65. Hamed, K.H. Trend detection in hydrologic data: The Mann-Kendall trend test under the scaling hypothesis. J. Hydrol. 2008, 349, 350-363. [CrossRef]

66. Mavromatis, T.; Stathis, D. Response of the water balance in Greece to temperature and precipitation trends. Theor. Appl. Climatol. 2011, 104, 13-24. [CrossRef]

67. Yue, S.; Wang, C.Y. Applicability of prewhitening to eliminate the influence of serial correlation on the Mann-Kendall test. Water Resour. Res. 2002, 38, 4-1-4-7. [CrossRef]

68. Li, C.; Stevens, B.; Marotzke, J. Eurasian winter cooling in the warming hiatus of 1998-2012. Geophys. Res. Lett. 2015, 42, 8131-8139. [CrossRef]

69. Wang, L.; Chen, W. The East Asian winter monsoon: Re-amplification in the mid-2000s. Chin. Sci. Bull. 2014, 59, 430-436. [CrossRef]

70. Kayumov, A.; Novikov, V. (Eds.) The Third National Communication of the Republic of Tajikistan Under the UN Framework Convention on Climate Change; The Government of the Republic of Tajikistan: Dushanbe, Tajikistan, 2014; p. 155.

71. Gulakhmadov, A.; Chen, X.; Gulahmadov, N.; Liu, T.; Anjum, M.N.; Rizwan, M. Simulation of the Potential Impacts of Projected Climate Change on Streamflow in the Vakhsh River Basin in Central Asia under CMIP5 RCP Scenarios. Water 2020, 12, 1426. [CrossRef]

72. Pachauri, R.K.; Allen, M.R.; Barros, V.R.; Broome, J.; Cramer, W.; Christ, R.; Church, J.A.; Clarke, L.; Dahe, Q.; Dasgupta, P. Climate change 2014: Synthesis Report. Contribution of Working Groups I, II and III to the Fifth Assessment Report of the Intergovernmental Panel on Climate Change; IPCC: Geneva, Switzerland, 2014.

73. Barry, R.G.; Chorley, R.J. Atmosphere, Weather and Climate; Routledge: Abingdon, UK, 2009.

74. Barry, R.G.; Blanken, P.D. Microclimate and Local Climate; Cambridge University Press: Cambridge, UK, 2016.

75. Xin, J.; Gong, C.; Wang, S.; Wang, Y. Aerosol direct radiative forcing in desert and semi-desert regions of northwestern China. Atmos. Res. 2016, 171, 56-65. [CrossRef]

76. Bollasina, M.A.; Ming, Y.; Ramaswamy, V. Anthropogenic aerosols and the weakening of the South Asian summer monsoon. Science 2011, 334, 502-505. [CrossRef]

77. Folini, D.; Wild, M. The effect of aerosols and sea surface temperature on China's climate in the late twentieth century from ensembles of global climate simulations. J. Geophys. Res. Atmos. 2015, 120, 2261-2279. [CrossRef]

78. Pendergrass, A.G.; Knutti, R.; Lehner, F.; Deser, C.; Sanderson, B.M. Precipitation variability increases in a warmer climate. Sci. Rep. 2017, 7, 17966. [CrossRef]

79. Wang, C. Impact of anthropogenic absorbing aerosols on clouds and precipitation: A review of recent progresses. Atmos. Res. 2013, 122, 237-249. [CrossRef]

80. Jaweso, D.; Abate, B.; Bauwe, A.; Lennartz, B. Hydro-meteorological trends in the upper Omo-Ghibe river basin, Ethiopia. Water 2019, 11, 1951. [CrossRef]

81. Hagg, W.; Braun, L.; Weber, M.; Becht, M. Runoff modelling in glacierized Central Asian catchments for present-day and future climate. Hydrol. Res. 2006, 37, 93-105. [CrossRef]

82. Zhang, R.; Xu, Z.; Zuo, D.; Ban, C. Hydro-Meteorological Trends in the Yarlung Zangbo River Basin and Possible Associations with Large-Scale Circulation. Water 2020, 12, 144. [CrossRef]

83. Lee, C.-H.; Yeh, H.-F. Impact of Climate Change and Human Activities on Streamflow Variations Based on the Budyko Framework. Water 2019, 11, 2001. [CrossRef] 
84. Hamed, K.H.; Rao, A.R. A modified Mann-Kendall trend test for autocorrelated data. J. Hydrol. 1998, 204, 182-196. [CrossRef]

85. Yue, S.; Pilon, P.; Phinney, B.; Cavadias, G. The influence of autocorrelation on the ability to detect trend in hydrological series. Hydrol. Process. 2002, 16, 1807-1829. [CrossRef]

86. Team, R.C. R: A Language and Environment for Statistical Computing; R Foundation for Statistical Computing: Vienna, Austria, 2015; Volume 2018, p. 2013.

87. Patakamuri, S.; O’Brien, N.M. Modified Versions of Mann Kendall and Spearman's Rho Trend Tests 2019; The R Project for Statistical Computing: Vienna, Austria, 2019.

(C) 2020 by the authors. Licensee MDPI, Basel, Switzerland. This article is an open access article distributed under the terms and conditions of the Creative Commons Attribution (CC BY) license (http://creativecommons.org/licenses/by/4.0/). 